\title{
A Comprehensive Review on Droplet-based Bioprinting: Past, Present and
}

\section{Future}

\author{
Hemanth Gudupati ${ }^{1,3}$, Madhuri Dey ${ }^{2,3}$, and Ibrahim Ozbolat ${ }^{1,3, *}$ \\ ${ }^{1}$ Engineering Science and Mechanics Department, Penn State University, University Park, PA, 16802 \\ ${ }^{2}$ Department of Chemistry, Penn State University, University Park, PA, 16802 \\ ${ }^{3}$ The Huck Institutes of the Life Sciences, Penn State University, University Park, PA, 16802
}

\begin{abstract}
Droplet-based bioprinting (DBB) offers greater advantages due to its simplicity and agility with precise control on deposition of biologics including cells, growth factors, genes, drugs and biomaterials, and has been a prominent technology in the bioprinting community. Due to its immense versatility, DBB technology has been adopted by various application areas, including but not limited to, tissue engineering and regenerative medicine, transplantation and clinics, pharmaceutics and high-throughput screening, and cancer research. Despite the great benefits, the technology currently faces several challenges such as a narrow range of available bioink materials, bioprinting-induced cell damage at substantial levels, limited mechanical and structural integrity of bioprinted constructs, and restrictions on the size of constructs due to lack of vascularization and porosity. This paper presents a first-time review of DBB and comprehensively covers the existing DBB modalities including inkjet, electrohydrodynamic, acoustic, and micro-valve bioprinting. The recent notable studies are highlighted, the relevant bioink biomaterials and bioprinters are expounded, the application areas are presented, and the future prospects are provided to the reader.
\end{abstract}

Keywords: Bioprinting, Droplet-based bioprinting, Inkjet bioprinting, Electrohydrodynamic bioprinting, Acoustic bioprinting, Micro-valve bioprinting

\footnotetext{
* Corresponding author: Ozbolat, I.T., email: ito1@psu.edu, ph: +1(814)8635819
} 


\section{Introduction}

Three-dimensional (3D) bioprinting aims to fabricate tissue and organ constructs by selectively depositing biologics, such as living cells, biomaterials, drugs, growth factors and genes, in a layer-bylayer fashion [1-4]. It currently enables fabrication of scaffold-based or scaffold-free tissue and organ constructs [5], mini-tissues [3] and organ-on-a-chip models [6-9], and is envisioned to facilitate fabrication of functional replacement human organs such as heart, liver and kidney in the future [10]. However, bioprinting of such organs at present is impractical because of the challenges such as the need for built-in vascularization at the single-cell level and complex-heterocellular tissue patterning, and the development of biodegradable as well as biomimetic materials which are bioprintable while enabling rapid cell growth and proliferation $[2,3,11]$. Despite these challenges, 3D bioprinting serves in several other application areas. For example, 3D tissue models $[1,12]$ can improve in-vitro drug testing by replacing two-dimensional (2D) cell culture and animal models as animal models are not effective at predicting human toxicological and pathophysiological responses [13] and 2D culture models do not closely mimic complex 3D micro-tissue environment $[10,12,14]$. Bioprinted tissues have also been used in tissue engineering and regenerative medicine such as bioprinted bone and cartilage which can help in musculoskeletal injury healing and rehabilitation $[2,3,15]$. Furthermore, in-situ bioprinting, technology enabling bioprinting directly into lesion sites in surgery settings, can regenerate complex large tissues through neo-vascularization driven by nature in human body $[4,16,17]$. Overall, 3D bioprinting provides an opportunity to envision radical solutions to existing medical and healthcare problems.

Bioprinting offers three main types of modalities including laser- [18-20], droplet- [21-24] and extrusion-based bioprinting [25]. Despite the commonly used extrusion-based bioprinting and the highprecision laser-based bioprinting, droplet-based bioprinting (DBB) offers several advantages due to its simplicity, agility, versatility and the great control over the deposition pattern. It enables bioprinting 
with controlled volumes of bioink deposition at predefined locations [3] facilitating spatially heterocellular constructs with well-defined positioning of cells [11].

Droplet-based bioprinting has its roots in inkjet printing technology, which has its beginnings in the 1950s when Elmqvist of Siemens patented the first practical inkjet device in 1951 [26]. Later, Sweet from Stanford University spearheaded the development of continuous-inkjet (CIJ) printing system in 1960s. Later, Zoltan, Kyser, and Sears pioneered the development of drop-on-demand (DOD) inkjet printing system in 1970s. Their invention was licensed in the first commercial DOD inkjet printer, the Siemens PT-80, in 1977. The idea of printing biologics was first introduced by Klebe in 1987 when he used a commercially-available Hewlett-Packard (HP) thermal DOD inkjet printer to deposit a bioink solution comprising collagen and fibronectin [27]. Afterwards, the first inkjet-based 3D printer was developed by Objet Geometries in 2000 [28]. In 2003, Boland demonstrated the feasibility of using a modified thermal DOD inkjet printer to deposit living cells in a viable form [29] and introduced the concept of inkjet bioprinting [30]. Subsequently, Nakamura's group successfully fabricated viable 3D tubular tissue constructs using a commercially available electrostatic DOD inkjet printer [31]. Later, several research groups have successfully adopted DBB technologies for bioprinting of a wide array of cells for various purposes, including but not limited to, bioprinting for stem cell research [17,32-34], tissue engineering $[17,24,35,36]$, controlled release [37], transplantation [24,35], drug screening [38], high-throughput arrays [39], and cancer research [36,40].

In this paper, we present a first-time and thorough review of DBB technology including the modalities used with a comprehensive discussion on their working mechanisms, a detailed comparison of DBB with other bioprinting modalities, recent achievements in DBB, and bioink materials and bioprinters used in DBB. The application areas are discussed and future prospects with highly exciting directions are provided to the reader. 


\section{Droplet-based Bioprinting}

\subsection{Modalities of droplet-based bioprinting}

Droplet-based bioprinting, as shown in Fig. 1, comprises inkjet $[3,11,21,22,27,41-43]$, acousticdroplet-ejection (or simply acoustic) [44] and micro-valve bioprinting [32,33,40,45,46]. Inkjet bioprinting is classified into three: (i) CIJ, (ii) DOD and (iii) EHD jetting. Continuous-inkjet bioprinting leverages Rayleigh-Plateau instability to break bioink jets into droplets. Drop-on-demand bioprinting, on the other hand, uses thermal or piezoelectric actuators, or electrostatic forces to generate droplets. In contrast, electrohydrodynamic jet (EHD) bioprinting uses high-ranges of electric voltage to eject droplets. Whereas, acoustic bioprinting uses acoustic waves to produce droplets and micro-valve bioprinting uses a solenoid pump to eject droplets.

\subsubsection{Inkjet bioprinting}

Inkjet bioprinting physically manipulates a bioink solution to generate droplets. It leverages gravity, atmospheric pressure and the fluid mechanics of the bioink solution to eject droplets onto a receiving substrate.

\subsubsection{Continuous-inkjet bioprinting}

In $\mathrm{CIJ}$ bioprinting, the bioink solution is forced under pressure through a nozzle, which subsequently breaks up into a stream of droplets owing to Rayleigh-Plateau instability [47] as illustrated in Fig. 2A1. The phenomenon of Rayleigh-Plateau instability has been described elsewhere in details [48] but briefly, a cylindrical volume of liquid jet is perturbed by several factors including but not limited to the potential energy owing to surface energy of the jet and the kinetic energy due to motion of the jet. When the wavelength of the perturbed jet exceeds its initial radius by a certain limit (such that the product of the wave number $(k)$ (the number of waves per unit length) and the initial jet radius $\left(R_{0}\right)$ is 
less than $\left.1\left(k R_{0}<1\right)\right)$, the perturbation grows exponentially and eventually the jet distorts itself to minimize its potential energy and breaks up into a stream of droplets.

\subsubsection{Drop-on-demand inkjet bioprinting}

Drop-on-demand inkjet bioprinting is preferred over $\mathrm{ClJ}$ bioprinting for tissue bioprinting purposes. Drop-on-demand inkjet bioprinters generate droplets when required, which makes them more economical, handy to control and easy to pattern biologics [49]. Drop-on-demand bioprinters consist of a single or multiple printheads. Each printhead contains a fluid chamber and a single or multiple nozzles. The bioink stored in the fluid chamber is held in place by the surface tension at the nozzle orifice [49]. Pressure pulses are introduced in the fluid chamber through means of a thermal or a piezoelectric or an electrostatic actuator such that a droplet is ejected when the bioink overcomes the surface tension. Some printhead assemblies may require back pressure (pneumatic pressure (static pressure through means of pressurized-air) and/or vacuum) to supplement the pressure pulses for droplet generation. Drop-on-demand inkjet bioprinters rely on three different mechanisms to generate droplets including (i) thermal inkjet (TIJ), (ii) piezoelectric inkjet (PIJ) and (iii) electrostatic bioprinting. Thermal inkjet bioprinters generate droplets using a thermal actuator whereas PIJ bioprinters generate droplets using a piezoelectric actuator [50]. The two techniques are identical in other aspects. Electrostatic bioprinting, in contrast, ejects droplets using an electrostatic force $[31,51]$.

\subsection{Thermal inkjet bioprinting}

The thermal actuator in TIJ bioprinting locally heats the bioink solution when a voltage pulse is applied. The localized heating forms a vapor bubble as shown in Fig. 2A2. Subsequently, the bubble expands rapidly and collapses (explodes), which generates a pressure pulse inside the fluid chamber $[52,53]$. Consequently, the bioink overcomes the surface tension at the nozzle orifice and a droplet is 
ejected. Thermal inkjet bioprinters are capable of dispensing various biologics such as proteins and mammalian cells and are summarized in Table 1.

The bioprinted cells retained their functional phenotype and genotype, and proliferation capacity $[17,54-56]$. In summary, bioprinting studies pertaining TIJ bioprinting technology to date have been to assess its impact on the functionality of bioprinted cells. For example, Figs. 3A1-2 show TIJbioprinted neurons tagged with neural markers at 15 days after bioprinting. As seen in the figure, TIJ bioprinting did not affect the neuronal phenotype and electrophysiological functions of the bioprinted neurons. Furthermore, a myriad of studies have utilized modified commercial 2D thermal inkjet printers and explored their role in tissue regeneration such as cardiac tissue (see Fig. 3B) [57], vascular tissue [52] and in-situ cartilage repair [56].

\subsection{Piezoelectric inkjet bioprinting}

Piezoelectric bioprinters, similar to TIJ bioprinters, are suitable for bioprinting various biologics. The piezoelectric actuator in PIJ bioprinting changes its shape when a voltage pulse is applied, as depicted in Fig. 2A3. This deforms the fluid chamber [50], in which a sudden change in the volume of the fluid chamber causes a pressure wave. As a result, the surface tension at the nozzle orifice is overcome and a droplet of the bioink is ejected [58]. Overall, studies on PIJ bioprinting technology have thus far investigated the feasibility and possibility of fabricating 3D tissue constructs $[9,11,59,60]$. For example, Fig. $3 \mathrm{C}$ depicts a PIJ-bioprinted vascular-like tissue construct with horizontal and vertical bifurcations. The tissue construct comprising alginate and NIH3T3 cells was fabricated by a single nozzle PIJ bioprinter. Further, some studies optimized process parameters, including the bioink constituents [61], piezoelectric element actuation modes (pull-push and push-pull) [62], and voltage pulse characteristics (amplitude, rise and fall times, dwell time, echo time, and frequency) [11,60], to improve process efficiency. Furthermore, few other studies attempted to improve process reliability [63] and control the 
number of encapsulated cells in ejected droplets for potential applications in the areas of diagnostics, therapeutics and cell biology $[62,64]$.

\subsection{Electrostatic bioprinting}

Electrostatic bioprinters, identical to PIJ bioprinters, generate droplets by temporarily increasing the volume of the fluid chamber, without heating the bioink unlike TIJ bioprinters [51]. The brief increase in the volume of the fluid chamber as well as the bioink solution is achieved through the means of a pressure plate as shown in Fig. 2A4. The pressure plate deflects when a voltage pulse is applied between the plate itself and an electrode. The pressure plate regains its original shape in the absence of the voltage pulse and subsequently ejects droplets. Electrostatic bioprinters have been primarily used by Nakamura's group [31] to fabricate 3D acellular (see Fig. 3D) as well as cellular constructs comprising of HeLa cells.

\subsubsection{Electrohydrodynamic jet bioprinting}

Drop-on-demand bioprinters generate droplets by propelling bioink solutions through a nozzle. Hence, a very high level of pressure is required when ejecting cell-laden droplets through a nozzle with an extremely small orifice diameter, which is at times harmful to cells. In contrast, EHD bioprinters use an electric field to pull the bioink droplets through the orifice obviating the need for a substantially high pressure [42]. As a result, EHD bioprinters are ideal for bioprinting applications requiring nozzles with very small orifice diameters $(\leq 100 \mu \mathrm{m})$ and highly concentrated bioinks (up to $20 \%$ weight by volume) [41]. The working mechanism of EHD bioprinting is illustrated in Fig. $2 A 5[42,65,66]$, where a bioink solution is fed through a metallic nozzle using a certain back pressure such that the bioink forms a spherical meniscus at the tip of the nozzle owing to the surface tension [67]. A high voltage range $(0.5$ $\mathrm{kV}-20 \mathrm{kV}$ ) $[66,68]$ is applied between the nozzle and the substrate, which generates an electric field (as a function of the applied voltage and the distance between the nozzle and the substrate) between them. 
As a result, the electric field leads to the accumulation of mobile ions in the bioink near the surface of the suspended bioink meniscus. Subsequently, the Columbic or the electrostatic repulsions between the ions deform the meniscus into a conical shape called a "Taylor cone." Consequently, bioink droplets are ejected when the electrostatic stresses overcome the surface tension at the orifice under a sufficiently high voltage depending on the process parameters. The strength of the electric field (applied voltage), the bioink flow rate and the bioink properties (including cell type and concentration [69]) determine the jetting mode $[42,70]$ and cell viability [71]. Dripping mode is observed at low voltages and flow rates, whereas streams of distinct droplets are seen at intermediate voltages and/or flow rates. At the same time, a continuous stream of the bioink, known as cone-jet-mode (continuous presence of a Taylor cone), is observed at high voltages.

Although process parameters do not significantly affect the cell viability (see Table 2 ) and genomic expression immediately after bioprinting, applied voltage, cell concentration and bioink constituents can collectively affect the long-term post-bioprinting cell viability [71]. The applied voltage determines the ejected droplets size $[43,71]$ whereas bioink constituents (such as hydrogels including but not limited to crosslinked alginate, collagen and fibrin) and concentration used for cell encapsulation alter the diffusion of media. Hence, the droplet size and bioink constituents affect media transport to the encapsulated cells. The cell concentration also affects the number of cells encapsulated in each droplet and thus the availability of media to individual cells. In general, the droplets size decreases when the applied voltage increases and the media transport is not effective when the droplet size exceeds 400 $\mu \mathrm{m}$.

Electrohydrodynamic jet bioprinting studies to date have investigated the practicality of bioprinting living cells and for understanding the effect of process parameters on characteristics of ejected droplets. For example, Fig. 3E shows EHD-bioprinted porcine vascular smooth muscle cells 
(PVSMCs) after 40 days post-bioprinting. Subsequent, flow cytometric analysis indicated that the bioprinted cells retained their viability [72]. In summary, EHD bioprinters generate a continuous jet or a stream of droplets at a time rather than a single droplet. Hence, they are not suitable for bioprinting applications requiring very accurate placement of cells.

\subsubsection{Acoustic bioprinting}

Acoustic bioprinting, as illustrated in Fig. 2C, employs a gentle acoustic field to eject droplets from an open pool unlike inkjet bioprinting, which ejects droplets through a nozzle [23]. As a result, the bioink and the constituent living cells are not exposed to detrimental stressors such as heat, high pressure, large voltage, and significant shear stress during droplet ejection. Typically, an acoustic bioprinter consists of a single or an array of 2D micro-fluidic channels, in which the bioink is held in place owing to the surface tension at the small channel exit. Further, the bioprinter setup generally consists of a piezoelectric substrate and interdigitated gold rings placed on the substrate to generate surface acoustic waves on demand. The waves are circular in geometry and form an acoustic focal point at the interface between the air and the bioink near the channel exit. The droplets are ejected when the force, exerted by the acoustic radiation at the focal point, exceeds the surface tension at the exit of the channel $[23,73]$.

Bioprinting often involves printhead and/or substrate movement; however, a moving printhead and/or a substrate can introduce undesirable disturbances in acoustic-based bioprinting when compared to nozzle based systems including inkjet bioprinters. Consequently, the disturbances can bring loss of control over the droplet ejection. In addition, gentle acoustic fields may not be capable of ejecting droplets of viscous bioinks such as hydrogels with high cell concentrations. Sadly, studies investigating acoustic-based bioprinting are very few to date. Acoustic-based bioprinting has enabled 
bioprinting of a myriad of cell types. For example, Fig. 3F shows acoustically bioprinted AML-12 cells after 12 days post bioprinting [23]. The bioprinted cells were viable and became confluent in 12 days.

\subsubsection{Micro-valve bioprinting}

Micro-valve bioprinting uses an electromechanical valve to generate droplets as shown in Fig. $2 \mathrm{D}[45,46,74]$. The bioink in the fluid chamber is pressurized (back pressure) and the nozzle orifice is gated by a micro-valve. A typical micro-valve consists of a solenoid coil and a plunger which blocks the orifice. The valve coil generates a magnetic field when a voltage pulse is applied and the magnetic field pulls the plunger upwards. As a result, the nozzle is unblocked and the bioink is ejected out when the back pressure is sufficiently large enough to overcome the surface tension at the orifice. The back pressure and the valve-gating time determine the mode of the droplet generation, either CIJ or DOD.

Micro-valve bioprinters are favorable for bioprinting various proteins and cells. Process parameters, such as pneumatic pressure, nozzle geometry, cell concentration and the bioink constituents, determine the droplet volume as well as the cell viability [32]. For example, a nozzle with an orifice diameter of $150 \mu \mathrm{m}$, a pneumatic pressure of $6.89 \mathrm{kPa}(1 \mathrm{psi})$ and a valve open/close duration of $450 \mu \mathrm{s}$, generated cell suspension droplets (either fibroblasts with $10^{6}$ cells $/ \mathrm{ml}$ density in culture media or keratinocytes with $10^{6}$ cells/ml density in culture media) of $250 \mu \mathrm{m}$ in diameter $(8.1 \pm 2.1 \mathrm{~nL})$ [46]. At the same time, the same nozzle with a pneumatic pressure of $13.79 \mathrm{kPa}(2 \mathrm{psi})$ and a valve open/close duration of $600 \mu \mathrm{s}$ generated collagen droplets $(2.05 \mathrm{mg} / \mathrm{ml}$ of rat tail origin Type I collagen precursor) of $240 \mu \mathrm{m}$ in diameter $(7.6 \pm 2.7 \mathrm{~nL})$. The bioprinted cells retained their functionality, phenotype and genotype, and proliferation capacity (see Figs. 3G1-3) [46]. In addition, the differentiation capacity of human stem cells were not affected by the bioprinting process [32,33].

In summary, studies pertaining micro-valve bioprinting technology to date have examined the impact of bioprinting process on cell viability and functionality. Indeed, studies demonstrating the 
fabrication of complex 3D tissue constructs, similar to PIJ studies [11,60], are lacking. Overall, microvalve bioprinters require low-range of pneumatic pressure compare to that of PIJ bioprinters and hence they are less prone cell injury and damage [46]. However, micro-valve bioprinters dispense larger droplets than other DBB modalities (including TIJ, PIJ and EHD bioprinters) when identical nozzles are used [44]. Thus, the resolution of micro-valve bioprinters is lower than that of TIJ and PIJ bioprinters.

\subsection{Droplet-substrate interactions}

In addition to jet formation, impingement of a droplet onto the substrate is also crucial during DBB as it affects the fidelity and spreading of the droplet. While the ultimate goal of bioprinting is to pattern the cells and fabricate 3D tissue constructs, the ideal placement of droplets should accommodate the preservation of the droplet integrity as splashing or spreading of the droplet results in displacement of the deposited cells from their desired position or structural failure in 3D bioprinting. For viscoelastic hydrogels used in DBB, there exist two major impingement characteristics including splashing and spreading of the droplet. In splashing, the droplet disintegrates into secondary droplets after colliding with a substrate. In spreading, on the other hand, the droplet spreads over the surface and expands its surface area. According to Worthington, the droplet shape highly depends on the velocity of the droplet, where higher velocity generates splashing and lower velocity leads to spreading [75]. According to Weber, the critical number $\left(W_{e}\right)$ of droplet splashing is formulated as:

$$
W e=\frac{\rho d U^{2}}{\sigma}
$$

where $\rho$ is the density of the liquid, $d$ is the characteristics length which corresponds to the diameter of the droplet, $U$ is the velocity and $\sigma$ is the surface tension. In general, larger Weber numbers generates splashes and lower ones leads to spreading. As these properties are important for the droplet formation [76-78], properties of the substrate is also important as the factors including but not limited to wettability of the surface, surface roughness as well as viscous forces [79]. Furthermore, the 
spreading of the droplet occurs faster than its polymerization in a typical bioprinting setup [61] and the parameters associated with the crosslinking mechanism (i.e., ionic crosslinker solution concentration) influences the spreading behavior of the droplet [55]. Droplet-substrate interactions broadly consist of two regimes from a fluid mechanics perspective $[77,80]$. The first is the dynamic regime during which the kinetic energy of the droplet is dissipated. The second is the viscous dissipation regime during which surface energy interactions between the droplet and the substrate determine the spreading of the droplet to an equilibrium shape. In addition, gravity has minimal influence on landing and spreading of the droplet [81].

Transitioning from 2D (on a substrate) to 3D bioprinting necessitates a 3D printing mechanism, which enables fabrication of 3D constructs through deposition of droplets in a layer-by-layer fashion. Depending on the utilized hydrogel and its crosslinking mechanisms, four types of 3D printing schemes have been utilized in fabrication of tissue constructs including (i) alternating printing of the bioink and the crosslinker solutions (Fig. 4A), (ii) bioprinting of the bioink solution into a reservoir filled with the crosslinker solution (Fig. 4B), (iii) bioprinting of the bioink solution followed by spraying the crosslinker solution on top (Fig. 4C), and (iv) bioprinting of the bioink solution followed by exposing it to an ultraviolet (UV) source (Fig. 4D). As fabricating scale-up tissue constructs necessitates the integration of vascular networks, such vascularization can be generated by printing thermally-crosslinking sacrificial materials (i.e., gelatin) and liquefying them thereafter, which is also discussed in Section 5.2.1 under vascular tissue fabrication.

The resolution at which the 3D construct is fabricated depends on various factors including the volume and velocity of ejected droplets, droplet-substrate and droplet-droplet interactions, and the applied crosslinking mechanism. The volume of ejected droplets is mediated by several operating parameters such as the bioink material characteristics, the printhead geometry (orifice diameter) and its actuation voltage pulse characteristics $[23,32,36,43,46,71,82,83]$. For example, the width of each 
coalesced line in Fig. 4A depends on several fabrication parameters including the volume of droplets, the spacing between droplets and the printing speed, which consequently controls the bioprinting resolution [11,31,84]. In addition, how droplets interact with the substrate affects the spreading behavior of the droplet, which consequently affects the bioprinting resolution $[76,77,81,85]$.

\subsection{Droplet-based bioprinters}

Droplet-based bioprinting was pioneered by Klebe in the 1980s and later by Boland's group at Clemson University in early 2000s. Commercially available Canon and HP paper printers, based on TIJ mechanism, were adapted to bioprint various tissue constructs comprising proteins and cells. However, paper printers are not suitable for bioprinting as ink cartridges are prone to clogging and are difficult to clean when bioprinting viscous bioinks such as living cells with collagen. Additionally, printheads move along only one axis and are not capable of bioprinting even in 2D without introducing the motion capability to the substrate. Nakamura's group at University of Toyama circumvented the movement limitations of the paper printers by building a custom bioprinter in mid-2000s. The bioprinter was built using commercially available stepper motors and EPSON SEA-Jet ${ }^{\mathrm{TM}}$ (electrostatic) printheads. The bioprinter was used to fabricate 3D hollow tubular tissue constructs comprising HeLa cells [31] to further Boland's work [30].

Commercially available DOD printheads, such as EPSON SEA-Jet ${ }^{\mathrm{TM}}$, Fuji piezoelectric Dimatix $^{\mathrm{TM}}$, and Xaar-126 piezoelectric printheads consist of several nozzles connected to a single fluid chamber. The ejected droplets range from 1 to $100 \mathrm{pl}$ (with droplet diameters of 10-60 $\mu \mathrm{m}$ ), which are highly small and thus limit the use of some large cell types and bioink constituents. At the same time, single nozzle piezoelectric printheads, such as MicroFab printheads, offer a greater control over the droplet generation (number of droplets) and the droplet placement, and are more suitable for fabricating complex 3D tissue constructs. However, small secondary droplets, known as satellite droplets [86], often 
accompany the primary droplets affecting the bioprinting resolution [60]. In addition, printheads are prone to clogging if the bioink viscosity is high.

Micro-valve bioprinters, in contrast, are suitable for bioprinting viscous bioinks as the droplets ejection is primarily governed by the valve opening time. However, they are not suitable for highresolution bioprinting applications as the diameter of the ejected droplets [87] is greater when compared to other DBB modalities under the identical nozzle orifice diameter [44]. According to [44], the smallest droplets that can be generated by micro-valve bioprinters are $100 \mu \mathrm{m}$ in diameter as opposed to $50 \mu \mathrm{m}$ of inkjet (thermal and piezoelectric) bioprinters and $10 \mu \mathrm{m}$ of acoustic bioprinters. Biofactory is a popular commercial micro-valve bioprinter and the smallest printable droplet size using the Biofactory bioprinter ranges from 5 to $10 \mathrm{~nL}(>100 \mu \mathrm{m})$ [126]. Although, EHD bioprinters generate droplets that are substantially smaller than the nozzle orifice opening, the bioprinters are not capable of ejecting a single droplet at a time as they eject a stream of multiple droplets or a jet. Hence, EHD bioprinters are not suitable for high precision (precise placement of droplets) bioprinting applications.

Overall, controlling the number of cells to be encapsulated in a single droplet is still a challenge, regardless of the DBB modality. Hence, an ideal DBB bioprinter that offers precise control over the number of encapsulated cells is highly desired. Also, the bioprinter has to deposit multiple cell types as well as various viscous bioinks simultaneously without experiencing any clogging issues. Furthermore, the bioprinter has to precisely place droplets without any accompanying satellite droplets or jets. Unfortunately, such a bioprinter is currently far from the reality and certain features are always compromised while choosing bioprinters for a specific application. A comparative evaluation of the presented DBB modalities is presented in details in Table 2.

\section{Biomaterials used in Droplet-based Bioprinting}


A bioprintable material comprising various biologics (i.e., cells, growth factors, deoxyribonucleic acid (DNA) or drugs loaded in a delivery medium such as media or hydrogels) which is employed to fabricate 3D constructs with or without the use of external stimulations is rightfully referred to as 'bioink.' Essential characteristics of bioink include low viscosity, suitable biodegradability and biocompatibility, enhanced cell adhesive properties, bioprintability and high mechanical strength. However, such characteristics limit the range of exploitable biomaterials for DBB. Therefore, a limited range of hydrogels are available as bioink in DBB. Alternatively, hydrogels are also used as a substrate material when their viscosity is higher and/or the nozzle orifice diameter is extremely small. Hence, cells and other biologics are directly bioprinted into them.

\subsection{The Bioink Consideration}

A limited range of hydrogels including alginate, collagen, fibrin, methacrylated gelatin (GelMA) and polyethylene glycol (PEG), have been used in DBB due to their own or their crosslinkers' ease of ejectability and the compatibility of their crosslinking mechanism with different DBB modalities.

Alginate, a naturally derived polysaccharide molecule, is a frequently used hydrogel in DBB [32]. It consists of alternating $\beta$-D-mannuronate $(M)$ and $\alpha$-L-guluronate $(G)$ units [88]. Alginate undergoes ionic crosslinking, through the negatively charged carboxylate ( $\left.\mathrm{COO}^{-}\right)$group which is present in its polymeric backbone. When the negatively charged $\mathrm{COO}^{-}$group is exposed to positively charged ions such as divalent calcium cations $\left(\mathrm{Ca}^{2+}\right)$, it yields a crosslinked hydrogel network. Exploiting this crosslinking mechanism of alginate with $\mathrm{CaCl}_{2}$, Atala's group fabricated heterogeneous tissue constructs comprising human amniotic fluid-derived stem cells (hAFSCs), canine smooth muscle cells (dSMCs), and bovine aortic endothelial cells (bECs) [17]. Alginate was also combined with several other materials to enhance the mechanical and functional properties of the fabricated constructs. Blaeser's group, for instance, fabricated a bifurcated vascular tissue construct using a composite blend of $3 \%(\mathrm{w} / \mathrm{v})$ low 
melting agarose and 3\% (w/v) low viscosity alginate [89]. The bioprinting process was performed under nontoxic fluorocarbon, which provided the necessary buoyancy forces needed to support the soft tissue structure. Additionally, Boland and his coworkers bioprinted the crosslinking solution $\left(\mathrm{CaCl}_{2}\right)$ using a modified HP DeskJet inkjet printer to fabricate a heart-like tissue construct with connected ventricles [57]. In another study, Huang's group mixed 3T3 fibroblast cells in $1 \%$ sodium alginate solution and bioprinted it into the crosslinker pool to fabricate zigzag cell-laden tubular constructs [11]. Similarly, alginate comprising hepatocyte-like cells, which were obtained through directed differentiation of human induced-pluripotent stem cells (hiPSCs), was bioprinted to fabricate a 3D mini-liver tissue model [32].

Collagen type-I is a triple helical protein which is a major component of ECM of several tissues in the human body [90]. It is a thermosensitive hydrogel and has been extensively exploited in tissue engineering for fabrication of tissue constructs due to its biocompatibility and cell adhesive properties [91]. In one study Boland's group used it as a bioink constituent to investigate adhesion and proliferation of cells on collagen-coated cell repellant substrates [91]. Also, Boland's group fabricated a bilayer skin graft, which generated neoskin identical to native skin with microvessels [92]. In another study, fibrin-collagen bioink comprising one of the two cell types, AFSCs or mesenchymal stem cells (MSCs), was bioprinted into wound sites for treating surgical skin wounds [93].

Methacrylated gelatin, a denatured collagen protein consisting of methacrylate groups conjugated to its amine side groups, has been increasingly used for engineering various tissues due to its appealing biological and controllable mechanical characteristics [94,95]. Although polymers derived from natural sources closely mimic the native extracellular matrix (ECM), they are inferior in mechanical strength. Methacrylated gelatin, in contrast, forms a biomimetic [94] as well as an enzymatically degradable [96] hydrogel that is mechanically strong when photocrosslinked with UV light in presence of 
a photoinitiator. For example, Demirci's group incorporated GelMA and growth factors (bone morphogenetic protein 2 (BMP-2) and transforming growth factor beta 1 (TGF- $\beta 1)$ ) as bioink constituents to imitate native fibrocartilage microenvironments which differentiated bioprinted hMSCs towards osteogenic and chondrogenic lineages spatially [33].

Fibrin, a hydrogel formed by the reaction of thrombin with fibrinogen, supports extensive cell growth and proliferation [52]. It plays a significant role in wound healing and has been used to fabricate skin grafts [92,93]. Boland's group used fibrin to engineer micro-capillaries by bioprinting human dermal microvascular endothelial cells (HMVECS)-laden thrombin and $\mathrm{Ca}^{2+}$ solution on a fibrinogen substrate [52]. Employing TIJ bioprinting, HMVECs were precisely bioprinted on crosslinked fibrin. Bioprinted HMVECs aligned well in fibrin and formed into an extensive capillary network after 21 days of culture. In another study, the same group bioprinted alternating layers of neural cells and fibrin gel to fabricate viable neural constructs for potential neural engineering applications [54]. In another study, Atala's group used fibrin to engineer cartilage tissue with enhanced mechanical and functional properties employing a hybrid method involving electrospinning and micro-valve bioprinting [35].

Polyethylene glycol, a polyether-based material, yields photolabile polymers when functionalized (addition of functional groups) with diacrylate (DA) or methacrylate (MA) [97]. Due to its greater mechanical strength compared to naturally-derived polymers, such as alginate, fibrin, agarose and collagen type-I, PEG is extensively used in DBB. Further, PEG is water soluble and its mechanical properties are controllable through variation of its chemistry [98]. Altering the composition of PEGbased hydrogels and photocrosslinking them in presence of a photoinitiator enables the control of structural, functional and mechanical properties of fabricated tissues. PEG-based hydrogels employed for cartilage tissue engineering have not only induced ECM production but also supported growth and proliferation of chondrocytes [99]. In that particular study, Cui et al. functionalized PEG with 
methacryloyl chloride and cultured human articular chondrocytes on PEGDMA hydrogel [99]. Using TIJ bioprinting, 3D constructs were fabricated by photocrosslinking cell-laden PEGDMA hydrogel in a layerby-layer fashion in the presence of 12959 photoinitiator. These cell-laden hydrogel constructs were then stimulated with insulin-transferrin-selenium (ITS) based medium supplemented with TGF- $\beta 1$ and fibroblast growth factor (FGF-2). The study revealed high cell proliferation and chondrogenic ECM deposition on the printed constructs due to the synergistic action of these growth factors, which eventually led to neo-cartilage formation $[56,99]$. In a similar study, acrylated-PEG was bioprinted with acrylated-peptide containing the Arg-Gly-Asp (RGD) sequence (essential for cell adhesion), followed by photopolymerization of the each bioprinted layer, resulting in 3D constructs comprising hMSCs [98]. The bioprinted hMSCs were successfully differentiated towards osteogenic and chondrogenic lineages. In another study, bone marrow-derived hMSCs were suspended in PEGDMA in conjunction with bioactive glass (BG) and hydroxyapatite (HA) nanoparticles, and bioprinted using a TIJ bioprinter [100]. This approach allowed control over the spatial delivery of hMSCs and bioactive ceramic materials in the fabricated bone tissue constructs (with a diameter of $4 \mathrm{~mm}$ and a thickness of $4 \mathrm{~mm}$ ).

There are a limited number of hydrogels that can be employed in DBB owing to very fine nozzle diameters. Therefore, it is essential to use bioinks with low viscosity to obviate nozzle clogging issues. Bioprintability, cost, crosslinking mechanisms, and viscosity are some of the factors which are essential to consider while selecting a bioink for DBB. Generally, natural hydrogels are preferred over synthetic ones as they possess inherent cell adhesive motifs and are able to mimic the ECM of the native tissue better. However natural hydrogels are mechanically poor and have higher or uncontrolled degradation rates. Natural hydrogels such as collagen is an integral protein found in extracellular matrices of most tissue types. Its ease of crosslinking under physiological temperature or increased pH makes it a suitable material for skin, cartilage, neural and vascular tissue engineering applications. Similarly, other naturallyderived hydrogels, such as fibrin and alginate, can be used for tissues that do not involve load bearing 
applications. Although synthetic hydrogels such as PEG do not inherently possess bioactive sites, they can be designed to conjugate the RGD sequence to enhance its cell adhesive properties. Additionally, synthetic hydrogels are mechanically strong and can be employed for bone tissue engineering applications. A comparison of the abovementioned hydrogels is presented in Table 3.

\subsection{The Substrate Consideration}

In addition to bioprinting hydrogels, a myriad of endeavors has been made to bioprint macromolecules (i.e., growth factors, proteins or even cells in media) directly onto hydrogel substrates. By controlling the spatial distribution of growth factors on hydrogel substrate, differentiation of stem cell into specific lineages have been widely attempted. Phillippi et al. used cyanin-3-labeled BMP-2 in media as a bioink solution and bioprinted it on fibrin-coated glass slides using a PIJ bioprinter [101]. They spatially immobilized BMP-2 with a varying concentration according to a predesigned pattern and cultured primary muscle-derived stem cells (MDSCs) on the BMP-2 patterned surface. This led to the differentiation of MDSCs into multiple lineages, namely osteogenic and myogenic in that study. Another study conducted by llkhanizadeh et al. showed that the fate and differentiation ability of neural stem cells could be effectively controlled by inkjet bioprinting of various macromolecules, such as fibroblast growth factor-2 (FGF2), ciliary neurotrophic factor (CNTF) and fetal bovine serum (FBS), on neural stem cell-seeded polyacrylamide-based (PA) hydrogel substrates [102].

Demirci's group fabricated coculture cancer models by bioprinting human ovarian cancer cells and fibroblasts in a controlled manner on Matrigel coated glass culture dish [40]. Collagen type I and fibrinogen has also been used as gel substrates for spatially-controlled bioprinting of HMVECs mixed in thrombin for fabricating skin grafts [92]. This bilayered skin graft comprising of keratinocytes and 
fibroblasts in collagen (as the top layer and bottom layer, respectively), and HMVECs encapsulated in fibrin network as the middle layer resulted in a portable construct, which was eventually placed on full thickness wounds in mice model for in-vivo studies. Polyacrylamide gel substrates have also been employed for micro-patterning proteins and cells by peeling off the protein from functionalized glass slides coated with PA substrates [103]. Poly(allylamine hydrochloride)/poly(styrene sulfonate) (PAH/PSS) based films were patterned on alginate gels for vascular tissue engineering by peeling off from the substrate as well [104]. These studies reveal the feasibility of bioprinting cells on gel substrates, and depending on the application, these substrate can be engineered to be peeled off for further studies.

\section{A Comparative Evaluation: Droplet-based Bioprinting versus Others}

Droplet-based bioprinting has several advantages and disadvantages with respect to other bioprinting techniques, including extrusion-based bioprinting (mechanical [105-109], pneumatic [110114] or valve-based [115-118]) or laser-based bioprinting (stereolithography [119] and its modifications [120], laser-guidance direct writing $[18,121]$ and laser-induced forward transfer $[19,122,123])$.

Droplet-based bioprinting technology is a multi-faceted technology. Highly complex heterocellular tissue constructs with different compositions of biologics (i.e., biomaterials, cells, growth factors, drugs, and genes) can be easily patterned when compared to extrusion- and laser-based bioprinting techniques as it is highly challenging to generate heterogeneity in a delicate manner using extrusion-based bioprinting and incorporating multiple types of biologics in laser-based bioprinting is difficult. While DBB has a process resolution higher than that of extrusion-based bioprinting and possesses a greater versatility in incorporating multiple biologics, DBB has attracted several researchers in the bioprinting community as well as researchers adopting bioprinting technology in other field of studies such as regenerative medicine and pharmaceutics $[38,124]$. Moreover, it has a reasonable resolution comparable to laser-based bioprinting, which allows better control on the geometry and size 
of bioprinted constructs by mediating the gelation process precisely as crosslinker and precursor hydrogel solutions can be selectively deposited. This enables mighty control on swelling and shrinkage properties of the bioprinted constructs.

Droplet-based bioprinters are highly versatile and affordable, where a simple HP printer can be easily modified and used as a bioprinter [125]. A wide range of droplet-based bioprinters are commercially available within affordable price range [126]. If the reproducibility and flexibility becomes a concern, extra capabilities can be easily implemented with a reasonable additional cost. For example, printheads in DBB may not be suitable for certain bioink materials such as fibrous bioink (i.e., fibrinogen and collagen) and generate inconsistent results due to nozzle clogging or accumulation of cell debris or fibers anywhere in the line from reservoir to the nozzle in the tubing system. A commercial dropletbased bioprinter can be modified to overcome such issues by replacing the original dispenser with dispensers having larger nozzles or dispensers with different droplet generation mechanisms as the rest of bioprinter sub-components are common for all DBB modalities.

Droplet-based bioprinting technology is also user-friendly and easy to implement. It can be readily used by operators, who have limited exposure to the technology while generated computeraided design (CAD) models can be easily transferred to print out by simply pressing 'bioprint.' In other words, it has a non-steep learning curve circumventing the need for extensive experimentation, which is a major impediment in extrusion-based bioprinting as the operator needs to understand the shearthinning behavior of hydrogels as well as their bioprintability on the printing stage.

The other advantage of DBB is that it facilitates rapid bioprinting through an array of nozzles in a highly reproducible manner. This capability enables rapid fabrication of an array of samples, which is highly desirable in high-throughput screening applications such as drug testing and cancer screening $[36,40,64]$. Producing high-throughput arrays using extrusion-based bioprinting, on the other hand, is 
highly challenging. In addition to its appealing features, DBB has a great translational potential in clinical use for tissue bioprinting. It is highly convenient for in-situ bioprinting purposes as defects (i.e., cranioor maxilla-facial defects, skin burns or deep wounds) on human body can be easily reconstructed using DBB as DBB operates in a non-contact manner. The defects can be easily filled by jetting droplets from a distance. This feature also enables bioprinting of growth factors or other biologics onto existing tissue constructs as biologics can be selectively sprayed over them [37]. The non-contact nature of DBB processes alleviates other major issues observed in extrusion-based bioprinting such as collision between the printhead and the bioprinted constructs, or unexpected increase in clearance between the orifice and the receiving substrate.

Despite these advantages, DBB possesses considerable limitations and drawbacks. One of the major limitations of DBB is the clogging of orifice during bioprinting process as highly small fragments in the bioink can accumulate within the orifice and obstruct the flow. This can sometimes necessitate the replacement of the entire orifice if the clogged material does not dissolve or cannot be removed. Because of the small orifice diameter ranging from 10 to $150 \mu \mathrm{m}$, as discussed before, a limited number of biomaterials are available for DBB such as low-viscosity hydrogels or their components. Thus, a wide majority of the bioink materials used in extrusion-based bioprinting, including cell aggregates, microcarriers and highly-viscous hydrogels [25], cannot be used in DBB. Due to this issue, researchers have preferred to create substrates of hydrogels and bioprint cells or other biologics on them using cell media as a delivery medium [33]. This approach has been widely employed for bioprinting arrays of droplets for high-throughput screening [39].

Although the non-contact nature of DBB provides great advantages as discussed before, gelation characteristics of printed droplets should be well experimented as ejected droplets can quickly gel in the air and do not assemble to the bioprinted substrate easily. The other limitation of DBB is the inability to 
fabricate mechanically strong and structurally well-integrated constructs due to the limited range of available bioink materials, particularly in high concentrations [127]. This can be however alleviated to some extent by infiltrating the bioprinted constructs within another biomaterial as a post-process. Alternatively, a reinforcement approach can also be employed, where nanofibers of stronger polymers can be reinforced into the inkjet bioprinted hydrogels using a hybrid fabrication setup [35].

While DBB facilitates fabrication of constructs in a discontinuous manner, where discrete droplets are assembled in 3D, it is highly challenging to fabricate porous tissue constructs. Porous tissue constructs are favorable for perfusion purposes to facilitate sufficient media exchange and can be easily bioprinted using extrusion- or laser- (only stereolithography and its modifications) based bioprinting techniques. Using DBB, porous architecture can be created either using a plotting medium as a support material with the help of buoyancy or utilizing a two-step approach such as applying porogens or fugitive hydrogels. Lastly, as the resolution of DBB is higher than that of extrusion-based bioprinting, it takes a longer time to fabricate scalable tissue constructs, where some minor issues can be experienced such as change in the size of the construct due to swelling, contraction or dehydration (when not bioprinted into the medium).

\section{Recent Achievements and Application Areas}

Droplet-based bioprinting has been widely used in the bioprinting community as well as other communities. In this section, recent achieves in the domain of DBB is presented and the applications areas are expounded.

\subsection{Recent achievements in droplet-based bioprinting}

Although clinical translation of DBB has been elusive, numerous recent breakthroughs in the areas of stem cell research, organs-on-chip models and regenerative medicine including tissue regeneration using in-situ bioprinting may make it eventually inevitable. To begin with, DBB does not 
affect stem cells functionality and differentiation capacity $[17,32,33,98]$. For example, Shu's group engineered 3D liver tissue models with hepatocytes derived from hiPSCs and human embryonic stem cells (hESCs) [32]. The group bioprinted a bioink solution (comprising hepatocytes and sodium alginate) using a micro-valve bioprinter to fabricate 3D tissue model (see Figs. 5A1-A2). During the bioprinting process, alternating layers of the bioink and crosslinker solutions (calcium chloride $\left(\mathrm{CaCl}_{2}\right)$ ) were bioprinted to enable the crosslinking of alginate. After 17 days post-bioprinting (after 23 days postdifferentiation), bioprinted cells maintained their differentiated phenotype, which was confirmed through the presence of hepatic markers such as hepatocyte nuclear factor 4 alpha (HNF4 $\alpha$ ) and albumin.

In another study, Atala's group demonstrated that bioprinted stem cells retained their functionality and the differentiation capacity both in vitro and in vivo [17]. The group bioprinted three different cell types, hAFSCs, dSMCs and bECs along with $\mathrm{CaCl}_{2}$ solution using a TIJ bioprinter. Consecutive layers of cell-laden $\mathrm{CaCl}_{2}$ crosslinker solution were bioprinted into a sodium alginatecollagen solution to fabricate 3D pie-shaped heterogeneous tissue constructs. The pie-shaped constructs were comprised of three distinct sections each with a particular cell type as shown in Fig. 5B1. Similarly, 3D cuboidal homogenous tissue constructs of each cell type were also fabricated. Later, bioprinted constructs were cultured for one week and subcutaneously implanted into outbred athymic nude mice. Afterwards, the constructs were surgically retrieved either after four or eight weeks (see Fig. 5B2). Subsequent analysis showed that biological functions (i.e., viability, proliferation, phenotypic expression, and physiological properties) of the bioprinted cells of each type were not affected significantly both in vitro and in vivo. Another notable observation was the vascularization of implanted bEC constructs with substantial blood vessels compared to that of control groups. 
On the other hand, achievements in regenerative medicine include tissue transplants $[35,92]$ and in-situ bioprinting [56] for improved wound healing. In a recent study [35], Atala's group engineered hybrid cartilage tissue by employing micro-valve bioprinting and electrospinning. In that study, a bioink solution comprising chondrocytes, fibrinogen and collagen was bioprinted into previously electrospun layers of poly- $\varepsilon$-caprolactone (PCL) fibers as illustrated in Figs. 5C1-2. In addition, thrombin was bioprinted on each bioprinted layer of the bioink solution to facilitate crosslinking. Afterwards, the constructs were cultured in vitro to evaluate cell proliferation and organization. Additionally, some constructs were cultured in vitro for two weeks and implanted subcutaneously in immunodeficient mice. Subsequently, the constructs were surgically retrieved after two, four, and eight weeks for characterization. The characterization study indicated that cartilage constructs maintained their biological functions both in vitro and in vivo. At the same time, the cartilage constructs possessed enhanced biological and mechanical characteristics than the cartilage constructs fabricated without incorporating the electrospun PCL fibers. Further, the constructs supported formation of a new cartilage-like tissue.

In-situ bioprinting is another achievement in regenerative medicine which is an alternative approach to two-step bioprinting (bioprinting followed by implantation), where cells and other biologics are directly bioprinted into lesion sites [56,93]. In one study [56], Lima's group engineered a cartilage tissue with comparable characteristics of the native cartilage. Using a TIJ bioprinter, human articular chondrocytes were bioprinted within photopolymerizable poly(ethylene) glycol dimethacrylate (PEGDMA) into circular defects in osteochondral explants. The explants were previously harvested from bovine femoral condyles using an 8-mm-diameter stainless steel punch. The defects in explants were repaired by bioprinting layers of chondrocytes and PEGDMA while crosslinking each bioprinted layer through photopolymerization. Afterwards, the repaired explants were cultured in vitro for two, four and six weeks post bioprinting. After four weeks, more chondrocytes with higher glycosaminoglycan (GAG) 
and collagen type II production were observed in tissue constructs bioprinted into the osteochondral explants than the constructs bioprinted in vitro (control group). Thus, in-situ bioprinting leveraged the presence of native cartilage tissue to accelerate chondrogenesis and extracellular matrix (ECM) production.

Similarly, Skardal and colleagues employed in-situ bioprinting to regenerate skin tissue with AFSCs and MSCs [93]. In order to compare their healing properties, the two cell types were separately bioprinted over surgical skin wounds $(2.0 \times 2.0 \mathrm{~cm})$ on the back (mid-dorsal region) of nude mice using a micro-valve bioprinter. Overall, three layers of thrombin solution and two layers of cell-laden collagenfibrinogen solution were alternatively bioprinted over the wounds resulting in $5 \times 10^{6}$ AFSCs or SMCs in each wound. Photographic images were taken immediately as well as seven and 14 days postbioprinting to monitor wound healing. Furthermore, regenerated skin was harvested from animals at seven and 14 days for histological analysis. Results indicated that AFSCs were comparable to MSCs in skin regeneration and in-situ bioprinting of cells overall accelerated the wound healing process.

\subsection{Application areas of droplet-based bioprinting}

Droplet-based bioprinting has been utilized in various application areas including (i) tissue engineering and regenerative medicine, (ii) transplantation and clinics, (iii) drug testing and highthroughput screening, and (iv) cancer research [128].

\subsubsection{Tissue engineering and regenerative medicine}

Engineering of tissues with comparable biological, anatomical, and physiological characteristics of their native counterparts is a great challenge [35]. Droplet-based bioprinting enables engineering tissues with native-like characteristics because of its ability to place various cell types accurately at a time [100]. It has been used to engineer tissues including bone $[61,88]$, cardiac [57], cartilage [59, 35, 33], liver [9, 32], lung [91], neural tissue $[34,81]$, skin $[58,92,93]$, vascular tissue $[67,94,95]$ and 
ovarian tumor tissue [38]. Various tissue types fabricated using DBB and other bioprinting modalities are compared in Table 4.

Bone tissue was engineered by Campbell's group in one study [101] by stimulating growth factor-dose-dependent differentiation of MDSCs towards osteogenic (bone) lineage employing BMP-2. Primary muscle-derived stem cells were cultured on BMP-2 patterns which were bioprinted on fibrin substrates using a PIJ bioprinter. The specificity of BMP-2 patterns essentially directed the dosedependent differentiation of MDSCs. Similarly, Cui's group in another study [100] engineered bone-like tissue with increased compressive modulus using a TIJ bioprinter. Human mesenchymal stem cells, photopolymerizable PEGDMA, and HA nanoparticles were simultaneously bioprinted at predefined 3D locations. The nanoparticles closely mimicked the native tissue microenvironments and stimulated the differentiation of stems cells towards osteogenic lineage with improved mechanical characteristics.

Cardiac (heart) tissue with beating response was engineered in one study using feline cardiomyoctyes, HL1 cardiac muscle cells and alginate hydrogel precursor [57]. The tissue was fabricated by bioprinting consecutive layers of $\mathrm{CaCl}_{2}$ on-demand at predefined locations using a TIJ bioprinter. After each layer was bioprinted, the substrate (mounted on a z-stage-stepper motor assembly) was submerged into a chamber filled with alginate hydrogel precursor solution (loaded with cells) to facilitate crosslinking. Subsequently, the substrate was brought up 100 microns below the initial position and the printing of $\mathrm{CaCl}_{2}$ was resumed. As cardiac cells are anchorage dependent and their attachment is governed by mechanical characteristics of the matrix, the periodic beating response of the individual bioprinted cells as well as the 3D tissue constructs as a whole suggested that cardiac cells attached to the alginate as it effectively mimicked the native cardiac ECM.

Cartilage tissue was engineered in three recent studies [33,35,56]. Atala's group fabricated cartilage tissue by bioprinting chondrocytes, fibrinogen, and collagen at predefined locations over a 
previously electrospun layer of PCL fibers using a micro-valve bioprinter [35]. Subsequently, thrombin was bioprinted to facilitate gelation. Meanwhile, Demirci's group fabricated a fibrocartilage tissue model through the directed differentiation of the bioprinted hMSCs with BMP-2 and TGF- $\beta 1$ [33]. Human MSCs were bioprinted using a micro-valve bioprinter together with photopolymerizable GelMA as well as the growth factors. The growth factors stimulated the differentiation of stem cells towards osteogenic and chondrogenic lineages, which was confirmed with quantitative reverse transcription polymerase chain reaction (RT-PCR) genomic expression analysis. Contrastingly, Lima's group fabricated cartilage tissue through in-situ bioprinting [56] as discussed in detail in Section 5.1.

Liver tissue was engineered in two individual studies conducted by Akashi et al. [9] and Shu et al. [32]. Akashi's group bioprinted liver tissue through layer-by-layer deposition of hepatocytes, endothelial cells, fibronectin, and gelatin using a PIJ bioprinter [9]. In that study, a single-layer to threelayer tissue models comprising of hepatocytes and liver endothelial cells (one layer of HepG2, two layers of HUVEC/HepG2, and three layers of HUVEC/HepG2/HUVEC) were fabricated. The tissue models were used for evaluating drug metabolism of anti-diabetic drug troglitazone. Similarly, Shu's group fabricated liver tissue with hepatocytes derived from hiPSCs and hESCs [32] as mentioned earlier in Section 5.1.

Lung tissue was engineered by Rothen-Rutishauser's group in a recent study [124]. The group fabricated an air-blood barrier model by bioprinting three distinct layers including alveolar epithelial type II (A549) cells, endothelial (EA.hy926) cells, and Matrigel ${ }^{\mathrm{TM}}$. A micro-valve bioprinter was employed for bioprinting the two cell types $\left(4.5 \times 10^{6} \mathrm{cells} / \mathrm{ml}\right)$ and the gel layer separating them, resulting in $1.4 \times$ $10^{5}$ cells $/ \mathrm{cm}^{2}$. At the same time, another identical tissue model (control) was fabricated by manually pipetting cells and the gel for comparative analysis. The bioprinted tissue model, because of precise placement of cells in close proximity, facilitated complex cell-to-cell communications between the two cell types. As a result, the bioprinted tissue model more closely resembled their native counterparts 
structurally and functionally. Whereas, the manually pipetted tissue model lacked direct cell-to-cell communications because of the thick intermediate gel layer, which resulted in aggregation of cells.

Neural tissue was engineered by Yoo's group in two studies using a micro-valve bioprinter. In the first study [87], neural tissue was fabricated by bioprinting eight alternating layers of either collagen precursor and rat embryonic neurons or collagen precursor and astrocytes with rat embryonic neurons. Each bioprinted layer of cells was separated by two bioprinted layers of collagen precursor solution. In addition, each bioprinted layer of collagen precursor solution was crosslinked with sodium bicarbonate $\left(\mathrm{NaHCO}_{3}\right)$ mist (droplets of diameter $<2 \mu \mathrm{m}$ ) before bioprinting the subsequent layers. In the second study [34], neural tissue was fabricated by stimulating the differentiation of neural stem cells (NSCs) using vascular endothelial growth factor (VEGF). The bioprinted tissue comprised of a single layer of NSCs and an adjacent circular layer of fibrin comprising VEGF which were sandwiched between two layers of collagen. In that study, stem cells neither proliferated nor migrated when the growth factors were absent.

Skin tissue was engineered recently in three studies $[92,93,129]$. Karande et al. in one study generated skin tissue in vitro with comparable biological and morphological characteristics of the native human skin [129]. The tissue was fabricated by bioprinting alternating layers of collagen, fibroblasts and keratinocytes using a micro-valve bioprinter. Initially, two layers of collagen precursor were bioprinted and each layer was crosslinked with $\mathrm{NaHCO}_{3}$ vapor. Subsequently, a layer of fibroblasts was bioprinted. Bioprinting of two collagen precursor layers followed by bioprinting of a single layer of fibroblasts was continued until six layers of collagen and three intermediate layers of fibroblasts were bioprinted. Finally, two layers of collagen followed by two layers of keratinocytes were bioprinted to complete the tissue fabrication. The bioprinted tissue constructs were partially submerged in culture medium and were cultured for 4-8 days. That is, keratinocytes were cultured at the air-liquid interface to promote 
their differentiation into corneocytes as well as the formation of stratum corneum. Subsequent histological characterization of the mature tissue cultures revealed that fibroblast density in the dermis was relatively lower and the ordered stratification of keratinocytes was incomplete when compared to native human skin. In summary, biological and morphological characteristics of the bioprinted skin tissue were comparable to native human skin.

Boland's group in another study [92] improved wound healing through bioprinted skin grafts. The skin grafts were fabricated by pipetting fibrinogen solution onto a layer of neonatal human dermal fibroblasts (NHDFs)-laden collagen. Subsequently, a layer of HMVECs-laden thrombin was bioprinted using a TIJ bioprinter onto fibrinogen. As a result, a fibrin-HMVEC layer was formed on the top of collagen-NHDF layer because of the interaction between fibrinogen and thrombin. Finally, neonatal human epidermal keratinocytes (NHEKs)-laden collagen was pipetted onto the fibrin-HMVEC layer. The grafts were incubated for 24 hours and were transplanted onto the previously made surgical wounds (skin incisions of $2 \mathrm{~mm}$ deep and $1.7 \times 1.7 \mathrm{~cm}$ wide) of nude mice. The wounds with grafted skin were completely healed in 14-16 days where as the wounds without the grafts (control group) healed in 21 days. Furthermore, the grafts supported the formation of new skin with comparable morphological characteristics of native skin but lacked sebaceous glands (SG), hair follicles and hair bulbs. At the same time, wounds without grafts suffered extensive scarring. In an alternative approach, Soker's group employed in-situ bioprinting to regenerate skin tissue with AFS cells and MSCs [93] as discussed earlier in Section 7.1.

Vascular tissue was recently engineered by Dai's group [130,131]. The group engineered capillaries through angiogenic sprouting of endothelial cells between two parallel vascular fluidic channels within a collagen construct [130]. Angiogenic sprouting of vascular networks is absolutely vital for tissue constructs at the clinically-relevant dimensions as vascularization of engineered tissue 
constructs has been elusive and remained obstacle on fabricating functional replacement human organs [4]. Angiogenic sprouting is a step towards addressing that challenge [114]. Figure 7D shows sprouted micro-capillaries out of bioprinted human umbilical vein endothelial cells (HUVECs) transfected with green fluorescent protein (GFP) and between the vascular channels seeded with HUVECs transfected with red fluorescent protein (RFP), 14 days post-bioprinting. Normal human lung fibroblasts (NHLFs) and GFP-transfected HUVECs were bioprinted in fibrinogen between the channels. Each bioprinted layer of fibrinogen was subsequently crosslinked with thrombin to facilitate fibrin formation. Capillaries between the two vascular channels began to sprout as early as day three.

\subsubsection{Transplantation and clinics}

Although a wide array of tissue types, such as skin [92], composite tissue [17], cartilage [35], bone [132] and vascular tissue [133], have been bioprinted using DBB technology and transplanted into animal models, translation of droplet-based bioprinted tissues into clinics for human use still remains elusive. Currently, a single exemplary case [134] demonstrated the transplantation of a 3D printed biodegradable airway splint, made of $\mathrm{PCL}$, into an infant after the approval of Food and Drug Administration (FDA) under the emergency-use exemption along with a written consent of the patient's parents. Although that study did not involve any cell or tissue printing attempt, translation of 3D printed scaffolds into clinics will be inspirational for bioprinting research and the case sets a precedent for translating bioprinting technologies from bench to bedside. In this regard, in-situ bioprinting technology is highly promising as cells and biologics can be bioprinted directly into the defect or wounded site on human body to repair body parts in operating settings. This technology, has been attempted using DBB technologies such as bioprinting of growth factors in cranium defects on rodent models [132] or bioprinting of skin cells on large deep wounds on rodent models [93]. Droplet-based bioprinting is the 
most convenient modality of bioprinting to deposit biologics into defects in surgery settings as it is a noncontact-based modality and does not entail any toxic and unsafe interventions during the surgery. Although the technology has been tested for animal models only, clinical translation will necessitate further advancements, testing and approval through regulatory pathway with the FDA. Bioprinting with growth factors and other biologics without using cells can transition earlier and further modifications can be pursued along the way with incorporating patient-specific cells into in-situ bioprinting technology. Food and Drug Administration has not imposed and laid down any regulations for the bioprinting technology and its components including bioink, bioprinters and bioprinted tissues and organs, and it is not clear how this technology will be categorized. Nonetheless, in-situ bioprinting is highly convenient for organs that are outside the body and accessible, and can be used for skin regeneration, maxillo- and cranio-facial reconstruction, plastic surgeries, tissue flaps or composite tissues repair for limb reconstruction.

\subsubsection{Drug testing and high-throughput screening}

Although micro-engineering techniques, such as surface patterning, soft-lithography and microfluidic-based manipulation [135] have been utilized in drug testing and high-throughput screening, DBB provides greater advantages such as high-precision control, repeatability and uniformity for fabrication of 3D micro-arrays. In this regard, Demirci and his coworkers demonstrated an acoustic-based bioprinting platform to bioprint a micro-array of SMCs on a collagen substrate [136]. The generated micro-array was then stimulated with different environmental conditions, such as temperature, in order to investigate the effect of the applied stimuli on cell fate. In a more recent study, Xu et al. presented an inkjet-based bioprinting approach to assemble a high-throughput miniature drug-screening platform [38]. A modified HP model 5360 compact disc printer was used to bioprint E. coli-laden alginate to generate a micro-array on a coverslip, followed by bioprinting of three different antibiotics (including penicillin/streptomycin, antimycotic, and kanamycin sulfate) on top of the bioprinted bacteria-laden 
hydrogel as shown in Figs. 5E1-2. The results revealed that the TIJ-bioprinted samples demonstrated similar cell viability and functionality, and anti-bacterial effects of antibiotics compare to micro-pipetted samples, confirming that TIJ bioprinting is as a powerful method to generate high-throughput arrays of samples for drug screening applications. In another work, Matsusaki et al. presented PIJ bioprinting of multi-layer liver tissue models on a 440 micro-well plate for drug screening and high-throughput applications [9]. In that work, a single-layer to three-layer tissue models comprising of hepatocytes and liver endothelial cells (one layer of HepG2, two layers of HUVEC/HepG2, and three layers of HUVEC/HepG2/HUVEC) were fabricated. Subsequently, the anti-diabetic drug troglitazone was used to evaluate the drug metabolism activity of tissue models by culturing them for a week. Albumin and CYP3A4 production in the cultured tissue models increased significantly with an increase in number of constituent cell layers. Thus, the presented work clearly demonstrated the potential of inkjet bioprinting for fabrication of a high-throughput liver tissue model for drug screening. Integration of DBB with microfluidics and microwell technology is new and our recent opinion article discusses how DBB can be used to bioprint multiple cell types into microwells for fabrication of heterocellular tissue models with controlled cell ratio and tissue size [137].

\subsubsection{Cancer research}

Mimicking a 3D cancer microenvironment is highly vital in order to understand cancer pathogenesis and metastasis [40]. Therefore, DBB has the great advantage in fabrication of highresolution tissue models with great repeatability. In the literature, only a few works have demonstrated DBB for cancer research as bioprinting has been recently adapted into this application area. In this regard, Demirci's group demonstrated bioprinting of tumor tissue models for in-vitro assays [40], where OVCAR-5 cells and MRC-5 fibroblasts were jetted using a dual-ejector system focusing on the same point. These two cell types were spontaneously bioprinted on Matrigel ${ }^{\mathrm{TM}}$ to generate multicellular acini in a high-throughput and reproducible manner with a spatially-mediated microenvironment with 
controlled cell density and cell-cell distance as illustrated in Fig. 5F. The resultant high post-bioprinting viability of the cells demonstrated the capability of DBB for in-vitro disease modeling and investigation of complex cell-to-cell communications including unknown regulatory mechanisms among various cell types.

\section{Future Prospects}

Different bioprinting modalities, including DBB, are envisioned to fabricate functional replacement human organs in the future $[10,138]$; however, several challenges have yet to be overcome to make it a reality. The first challenge is the printhead design for DBB. The physical characteristics of currently available printheads limit the control over several parameters including droplet volume, the number of cells to be encapsulated in each droplet, the precise placement of droplets, cell concentration, bioink material properties (viscosity) and the long-term reliability of the entire system. Printhead design constraints arise because of the current micro-fabrication processes, which impose several restrictions including the nozzle geometry. Hence, new nano- or micro-fabrication techniques are required to overcome the physical limitations with novel nozzle and printhead designs.

The second challenge is associated with materials that constitute the bioink. Each human organ is comprised of several billions of cells of various types [139]. Hence, acquiring cells such as stem cells in such quantities for autologous transplantation applications is constrained by cell cycle times, which may take several weeks to months $[140,141]$. Hence, new strategies for accelerating the cell cycle time are required. Another bioink-related challenge is the availability of biomimetic materials with controlled degradability and signaling cues to stimulate the proliferation and differentiation of cells [3]. For example, matrix material properties, such as elasticity, impacts the differentiation of bioprinted cells into specific phenotypes [142]. Thus, development of new materials or mechanisms that instill the bioink material with specific biomimetic characteristics, particularly after bioprinting, is desired as the nozzle geometry imposes material constraints. Growth factors and other signaling molecules could 
partially reduce the necessity of biomimetic materials; however, transporting them to specific bioprinted cells in a sustained manner over time imposes its own set of challenges. Perhaps, the transport of targeted growth factors and signaling molecules is possible by controlling the micro-pore geometry of bioprinted hydrogels such that of molecules of particular conformation (shape) are selectively transported.

The third challenge is the fabrication of 3D tissue constructs of complex conformations at submicrometer to micrometer resolution. For example, fabrication of complete vascular network at the single-cell level is challenging because DBB at high resolution is limited by the nozzle geometry, which constraints the droplet volume (size) and the bioink viscosity. Moreover, available bioprintable materials or hydrogels are characterized by weak mechanical strength and hence simultaneous co-deposition of degradable and biocompatible support materials is essential for counteracting gravity. Although, strategies such as support by means of liquid buoyancy have been proposed [60], leveraging natural mechanisms of cells is potentially most effective of all as it addresses several challenges at once. For instance, angiogenesis of micro-capillaries [130] obviates the co-deposition of support materials and the development of novel printheads with extremely small orifice diameter.

Currently, DBB is not capable of fabricating functional replacement human organs at clinicallyrelevant dimensions; however, it can improve drug discovery and disease modeling as it enables fabrication of spatially-patterned-multicellular microenvironments in a high-throughput and reproducible manner. Further, only a tiny tissue model can be sufficient for drug screening. At present, many drugs are not effective. For example, $97 \%$ of the patients see no benefits from anti-hypertensives [143] given for high blood pressure whereas $98 \%$ of the patients see no benefits from statins given for high cholesterol [144]. The low efficacy of prescription drugs can be attributed to the low numbers of human test subjects [145], which may not account for the genetic diversity among millions of patients. 
Bioprinted organ-on-a-chip models based on hiPSCs derived from diverse groups can account for the genetic variations and improve the drug discovery. Further, genomic analysis tools and individual genetic tests are becoming inexpensive and they can be used to personalize treatment plans or drug doses. Moreover, 3D tissue models are better at mimicking human physiology and pathology than currently used 2D cell culture models $[10,12,14]$ as well as the animal models [13]. Hence, DBB in combination with targeted genome editing tools such as CRISPR (clustered regularly interspaced short palindromic repeats)/CAS9 $[146,147]$ can improve disease modeling $[148,149]$.

\section{Conclusions}

Droplet-based bioprinting offers great advantages due to its simplicity, agility and versatility with great control on the deposition pattern. Although the technology currently enables fabrication of heterocellular tissue constructs in a high-throughput and reproducible manner, and has been widely used in several application areas such as tissue engineering and regenerative medicine, transplantation, drug testing and high-throughput screening, and cancer research, the technology currently faces several limitations such as weak structural and mechanical properties of bioprinted tissue and organ constructs as well as their lack of vascularization and perfusability, and the limited translation of the technology into clinics. Despite these limitations, novel breakthroughs such as angiogenesis and in-situ bioprinting, which leverage nature-driven mechanisms, make the eventual clinical translation of DBB technology inevitable.

\section{Acknowledgements}

This work has been supported by National Science Foundation CMMI Awards 1349716 and 1462232. The authors are grateful to the support from the Engineering Science and Mechanics Department at the Penn State University. The authors would like to thank Alyssa Sipos from Penn State University Biology Department for her assistance with the typesetting. The authors confirm that there 
are no known conflicts of interest associated with this publication and there has been no significant financial support for this work that could have influenced its outcome.

\section{References}

[1] V. Mironov, R.P. Visconti, V. Kasyanov, G. Forgacs, C.J. Drake, R.R. Markwald, Organ printing: Tissue spheroids as building blocks, Biomaterials. 30 (2009) 2164-2174. doi:10.1016/j.biomaterials.2008.12.084.

[2] B. Derby, Printing and prototyping of tissues and scaffolds, Science (80-. ). 338 (2012) 921-926. doi:10.1126/science.1226340.

[3] S. V Murphy, A. Atala, 3D bioprinting of tissues and organs, Nat. Biotechnol. 32 (2014) 773-785. doi:10.1038/nbt.2958.

[4] I.T. Ozbolat, Bioprinting scale-up tissue and organ constructs for transplantation, Trends Biotechnol. 33 (2015) 395-400. doi:10.1016/j.tibtech.2015.04.005.

[5] I.T. Ozbolat, Scaffold-based or scaffold-free bioprinting: competing or complementing approaches?, J. Nanotechnol. Eng. Med. 6 (2015) 024701. doi:10.1115/1.4030414.

[6] W. Wu, A. DeConinck, J.A. Lewis, Omnidirectional printing of 3D microvascular networks, Adv. Mater. 23 (2011) H178-83. doi:10.1002/adma.201004625.

[7] D. Huh, D.C. Leslie, B.D. Matthews, J.P. Fraser, S. Jurek, G.A. Hamilton, et al., A human disease model of drug toxicity-induced pulmonary edema in a lung-on-a-chip microdevice, Sci. Transl. Med. 4 (2012) 159ra147. doi:10.1126/scitranslmed.3004249.

[8] A.K. Capulli, K. Tian, N. Mehandru, A. Bukhta, S.F. Choudhury, M. Suchyta, et al., Approaching the in vitro clinical trial: engineering organs on chips, Lab Chip. 14 (2014) 3181-6. doi:10.1039/c4lc00276h.

[9] M. Matsusaki, K. Sakaue, K. Kadowaki, M. Akashi, Three-dimensional human tissue chips fabricated by rapid and automatic inkjet cell printing, Adv. Healthc. Mater. 2 (2013) 534539. doi:10.1002/adhm.201200299.

[10] F.P.W. Melchels, M.A.N. Domingos, T.J. Klein, J. Malda, P.J. Bartolo, D.W. Hutmacher, Additive manufacturing of tissues and organs, Prog. Polym. Sci. 37 (2012) 1079-1104. doi:10.1016/j.progpolymsci.2011.11.007.

[11] C. Xu, W. Chai, Y. Huang, R.R. Markwald, Scaffold-free inkjet printing of threedimensional zigzag cellular tubes, Biotechnol. Bioeng. 109 (2012) 3152-3160. doi:10.1002/bit.24591.

[12] S. Wüst, R. Müller, S. Hofmann, Controlled positioning of cells in biomaterialsapproaches towards 3D tissue printing, J. Funct. Biomater. 2 (2011) 119-154. doi:10.3390/jfb2030119.

[13] N. Shanks, R. Greek, J. Greek, Are animal models predictive for humans?, Philos. Ethics. 
Humanit. Med. 4 (2009) 2. doi:10.1186/1747-5341-4-2.

[14] T. Billiet, M. Vandenhaute, J. Schelfhout, S. Van Vlierberghe, P. Dubruel, A review of trends and limitations in hydrogel-rapid prototyping for tissue engineering, Biomaterials. 33 (2012) 6020-41. doi:10.1016/j.biomaterials.2012.04.050.

[15] H. V Unadkat, M. Hulsman, K. Cornelissen, B.J. Papenburg, R.K. Truckenmüller, A.E. Carpenter, et al., An algorithm-based topographical biomaterials library to instruct cell fate, Proc. Natl. Acad. Sci. U. S. A. 108 (2011) 16565-70. doi:10.1073/pnas.1109861108.

[16] A. Skardal, A. Atala, Biomaterials for integration with 3-D bioprinting, Ann. Biomed. Eng. 43 (2015) 730-46. doi:10.1007/s10439-014-1207-1.

[17] T. Xu, W. Zhao, J.-M. Zhu, M.Z. Albanna, J.J. Yoo, A. Atala, Complex heterogeneous tissue constructs containing multiple cell types prepared by inkjet printing technology, Biomaterials. 34 (2013) 130-9. doi:10.1016/j.biomaterials.2012.09.035.

[18] D.J. Odde, M.J. Renn, Laser-guided direct writing for applications in biotechnology, Trends Biotechnol. 17 (1999) 385-389. doi:10.1016/S0167-7799(99)01355-4.

[19] J.A. Barron, B.R. Ringeisen, H. Kim, B.J. Spargo, D.B. Chrisey, Application of laser printing to mammalian cells, Thin Solid Films. 453-454 (2004) 383-387. doi:10.1016/j.tsf.2003.11.161.

[20] L. Koch, S. Kuhn, H. Sorg, M. Gruene, S. Schlie, R. Gaebel, et al., Laser printing of skin cells and human stem cells., Tissue Eng. Part C. Methods. 16 (2010) 847-854. doi:10.1089/ten.tec.2009.0397.

[21] T. Xu, J. Jin, C. Gregory, J.J. Hickman, T. Boland, Inkjet printing of viable mammalian cells, Biomaterials. 26 (2005) 93-99. doi:10.1016/j.biomaterials.2004.04.011.

[22] P.A. Eagles, A.N. Qureshi, S.N. Jayasinghe, Electrohydrodynamic jetting of mouse neuronal cells, Biochem. J. 394 (2006) 375-8. doi:10.1042/BJ20051838.

[23] U. Demirci, G. Montesano, Single cell epitaxy by acoustic picolitre droplets, Lab Chip. 7 (2007) 1139-45. doi:10.1039/b704965j.

[24] F. Xu, S.J. Moon, A.E. Emre, E.S. Turali, Y.S. Song, S.A. Hacking, et al., A droplet-based building block approach for bladder smooth muscle cell (SMC) proliferation, Biofabrication. 2 (2010) 014105. doi:10.1088/1758-5082/2/1/014105.

[25] I.T. Ozbolat, M. Hospodiuk, Current advances and future perspectives in extrusion-based bioprinting, Biomaterials. 76 (2016) 321-43. doi:10.1016/j.biomaterials.2015.10.076.

[26] H.P. Le, Progress and trends in ink-jet printing technology, J. Imaging Sci. Technol. 42 (1998) 49-62.

[27] R.J. Klebe, Cytoscribing: a method for micropositioning cells and the construction of twoand three-dimensional synthetic tissues, Exp. Cell Res. 179 (1988) 362-73. doi:10.1016/0014-4827(88)90275-3.

[28] T. Wohlers, T. Gornet, History of additive manufacturing, Fort Collins, CO, 2012. 
[29] W.C. Wilson, T. Boland, Cell and organ printing 1: protein and cell printers, Anat. Rec. A. Discov. Mol. Cell. Evol. Biol. 272 (2003) 491-6. doi:10.1002/ar.a.10057.

[30] T. Boland, X. Tao, B.J. Damon, B. Manley, P. Kesari, S. Jalota, et al., Drop-on-demand printing of cells and materials for designer tissue constructs, Mater. Sci. Eng. C. 27 (2007) 372-376. doi:10.1016/j.msec.2006.05.047.

[31] Y. Nishiyama, M. Nakamura, C. Henmi, K. Yamaguchi, S. Mochizuki, H. Nakagawa, et al., Development of a three-dimensional bioprinter: construction of cell supporting structures using hydrogel and state-of-the-art inkjet technology, J. Biomech. Eng. 131 (2009) 035001. doi:10.1115/1.3002759.

[32] A. Faulkner-Jones, C. Fyfe, D. Cornelissen, J. Gardner, J. King, A. Courtney, et al., Bioprinting of human pluripotent stem cells and their directed differentiation into hepatocyte-like cells for the generation of mini-livers in 3D, Biofabrication. 7 (2015) 044102. doi:10.1088/1758-5090/7/4/044102.

[33] U.A. Gurkan, R. El Assal, S.E. Yildiz, Y. Sung, A.J. Trachtenberg, W.P. Kuo, et al., Engineering anisotropic biomimetic fibrocartilage microenvironment by bioprinting mesenchymal stem cells in nanoliter gel droplets, Mol. Pharm. 11 (2014) 2151-9. doi:10.1021/mp400573g.

[34] Y.B. Lee, S. Polio, W. Lee, G. Dai, L. Menon, R.S. Carroll, et al., Bio-printing of collagen and VEGF-releasing fibrin gel scaffolds for neural stem cell culture, Exp. Neurol. 223 (2010) 645-52. doi:10.1016/j.expneurol.2010.02.014.

[35] T. Xu, K.W. Binder, M.Z. Albanna, D. Dice, W. Zhao, J.J. Yoo, et al., Hybrid printing of mechanically and biologically improved constructs for cartilage tissue engineering applications, Biofabrication. 5 (2013) 015001. doi:10.1088/1758-5082/5/1/015001.

[36] Y. Fang, J.P. Frampton, S. Raghavan, R. Sabahi-Kaviani, G. Luker, C.X. Deng, et al., Rapid generation of multiplexed cell cocultures using acoustic droplet ejection followed by aqueous two-phase exclusion patterning, Tissue Eng. Part C. Methods. 18 (2012) 647-57. doi:10.1089/ten.TEC.2011.0709.

[37] G.M. Cooper, E.D. Miller, G.E. Decesare, A. Usas, E.L. Lensie, M.R. Bykowski, et al., Inkjetbased biopatterning of bone morphogenetic protein-2 to spatially control calvarial bone formation, Tissue Eng. Part A. 16 (2010) 1749-59. doi:10.1089/ten.TEA.2009.0650.

[38] J.I. Rodríguez-Dévora, B. Zhang, D. Reyna, Z. Shi, T. Xu, High throughput miniature drugscreening platform using bioprinting technology, Biofabrication. 4 (2012) 035001. doi:10.1088/1758-5082/4/3/035001.

[39] R. Suntivich, I. Drachuk, R. Calabrese, D.L. Kaplan, V. V. Tsukruk, Inkjet printing of silk nest arrays for cell hosting, Biomacromolecules. 15 (2014) 1428-35. doi:10.1021/bm500027c.

[40] F. Xu, J. Celli, I. Rizvi, S. Moon, T. Hasan, U. Demirci, A three-dimensional in vitro ovarian cancer coculture model using a high-throughput cell patterning platform, Biotechnol. J. 6 (2011) 204-12. doi:10.1002/biot.201000340. 
[41] S.N. Jayasinghe, A.N. Qureshi, P.A.M. Eagles, Electrohydrodynamic jet processing: an advanced electric-field-driven jetting phenomenon for processing living cells, Small. 2 (2006) 216-9. doi:10.1002/smll.200500291.

[42] M.S. Onses, E. Sutanto, P.M. Ferreira, A.G. Alleyne, J. a. Rogers, Mechanisms, capabilities, and applications of high-resolution electrohydrodynamic jet printing, Small. 11 (2015) 4237-66. doi:10.1002/smll.201500593.

[43] L. Gasperini, D. Maniglio, C. Migliaresi, Microencapsulation of cells in alginate through an electrohydrodynamic process, J. Bioact. Compat. Polym. 28 (2013) 413-425. doi:10.1177/0883911513501599.

[44] S. Tasoglu, U. Demirci, Bioprinting for stem cell research, Trends Biotechnol. 31 (2013) 10-9. doi:10.1016/j.tibtech.2012.10.005.

[45] A. Faulkner-Jones, S. Greenhough, J.A. King, J. Gardner, A. Courtney, W. Shu, Development of a valve-based cell printer for the formation of human embryonic stem cell spheroid aggregates, Biofabrication. 5 (2013) 015013. doi:10.1088/17585082/5/1/015013.

[46] W. Lee, J.C. Debasitis, V.K. Lee, J.-H. Lee, K. Fischer, K. Edminster, et al., Multi-layered culture of human skin fibroblasts and keratinocytes through three-dimensional freeform fabrication, Biomaterials. 30 (2009) 1587-95. doi:10.1016/j.biomaterials.2008.12.009.

[47] B. Derby, Bioprinting: inkjet printing proteins and hybrid cell-containing materials and structures, J. Mater. Chem. 18 (2008) 5717. doi:10.1039/b807560c.

[48] Lord Rayleigh, On the instability of jets, Proc. London Math. Soc. 10 (1878) 4-13.

[49] B. Derby, Inkjet printing of functional and structural materials: fluid property requirements, feature stability, and resolution, Annu. Rev. Mater. Res. 40 (2010) 395414. doi:10.1146/annurev-matsci-070909-104502.

[50] H. Wijshoff, The dynamics of the piezo inkjet printhead operation, Phys. Rep. 491 (2010) 77-177. doi:10.1016/j.physrep.2010.03.003.

[51] S. Kamisuki, T. Hagata, C. Tezuka, Y. Nose, M. Fujii, M. Atobe, A low power, small, electrostatically-driven commercial inkjet head, in: Proc. MEMS 98. IEEE. Elev. Annu. Int. Work. Micro Electro Mech. Syst. An Investig. Micro Struct. Sensors, Actuators, Mach. Syst. (Cat. No.98CH36176), IEEE, 1998: pp. 63-68. doi:10.1109/MEMSYS.1998.659730.

[52] X. Cui, T. Boland, Human microvasculature fabrication using thermal inkjet printing technology, Biomaterials. 30 (2009) 6221-7. doi:10.1016/j.biomaterials.2009.07.056.

[53] M.M. Mohebi, J.R.G. Evans, A drop-on-demand ink-jet printer for combinatorial libraries and functionally graded ceramics, J. Comb. Chem. 4 (2002) 267-74. doi:10.1021/cc010075e.

[54] T. Xu, C.A. Gregory, P. Molnar, X. Cui, S. Jalota, S.B. Bhaduri, et al., Viability and electrophysiology of neural cell structures generated by the inkjet printing method, Biomaterials. 27 (2006) 3580-8. doi:10.1016/j.biomaterials.2006.01.048. 
[55] T. Xu, H. Kincaid, A. Atala, J.J. Yoo, High-throughput production of single-cell microparticles using an inkjet printing technology, J. Manuf. Sci. Eng. 130 (2008) 021017. doi:10.1115/1.2903064.

[56] X. Cui, K. Breitenkamp, M.G. Finn, M. Lotz, D.D. D'Lima, Direct human cartilage repair using three-dimensional bioprinting technology, Tissue Eng. Part A. 18 (2012) 1304-12. doi:10.1089/ten.TEA.2011.0543.

[57] T. Xu, C. Baicu, M. Aho, M. Zile, T. Boland, Fabrication and characterization of bioengineered cardiac pseudo tissues, Biofabrication. 1 (2009) 035001. doi:10.1088/17585082/1/3/035001.

[58] M. Singh, H.M. Haverinen, P. Dhagat, G.E. Jabbour, Inkjet printing-process and its applications, Adv. Mater. 22 (2010) 673-685. doi:10.1002/adma.200901141.

[59] K. Arai, S. Iwanaga, H. Toda, C. Genci, Y. Nishiyama, M. Nakamura, Three-dimensional inkjet biofabrication based on designed images, Biofabrication. 3 (2011) 034113. doi:10.1088/1758-5082/3/3/034113.

[60] K. Christensen, C. Xu, W. Chai, Z. Zhang, J. Fu, Y. Huang, Freeform inkjet printing of cellular structures with bifurcations, Biotechnol. Bioeng. 112 (2015) 1047-55. doi:10.1002/bit.25501.

[61] K. Pataky, T. Braschler, A. Negro, P. Renaud, M.P. Lutolf, J. Brugger, Microdrop printing of hydrogel bioinks into 3D tissue-like geometries, Adv. Mater. 24 (2012) 391-6. doi:10.1002/adma.201102800.

[62] S. Yamaguchi, A. Ueno, Y. Akiyama, K. Morishima, Cell patterning through inkjet printing of one cell per droplet, Biofabrication. 4 (2012) 045005. doi:10.1088/17585082/4/4/045005.

[63] E. Cheng, A. Ahmadi, K.C. Cheung, Investigation of the hydrodynamics of suspended cells for reliable inkjet cell printing, in: ASME 2014 12th Int. Conf. Nanochannels, Microchannels Minichannels, ASME, 2014: p. V001T03A010. doi:10.1115/ICNMM201421583.

[64] A. Yusof, H. Keegan, C.D. Spillane, O.M. Sheils, C.M. Martin, J.J. O'Leary, et al., Inkjet-like printing of single-cells, Lab Chip. 11 (2011) 2447-54. doi:10.1039/c1lc20176j.

[65] E. Sutanto, K. Shigeta, Y.K. Kim, P.G. Graf, D.J. Hoelzle, K.L. Barton, et al., A multimaterial electrohydrodynamic jet (E-jet) printing system, J. Micromechanics Microengineering. 22 (2012) 045008. doi:10.1088/0960-1317/22/4/045008.

[66] L. Gasperini, D. Maniglio, A. Motta, C. Migliaresi, An electrohydrodynamic bioprinter for alginate hydrogels containing living cells, Tissue Eng. Part C. Methods. 21 (2015) 123-32. doi:10.1089/ten.TEC.2014.0149.

[67] M.J. Poellmann, K.L. Barton, S. Mishra, A.J.W. Johnson, Patterned hydrogel substrates for cell culture with electrohydrodynamic jet printing, Macromol. Biosci. 11 (2011) 1164-8. doi:10.1002/mabi.201100004. 
[68] I. Hayati, a. I. Bailey, T.F. Tadros, Mechanism of stable jet formation in electrohydrodynamic atomization, Nature. 319 (1986) 41-43. doi:10.1038/319041a0.

[69] S.N. Jayasinghe, A. Townsend-Nicholson, Stable electric-field driven cone-jetting of concentrated biosuspensions, Lab Chip. 6 (2006) 1086-90. doi:10.1039/b606508m.

[70] H.S. Kim, D.Y. Lee, J.H. Park, J.H. Kim, J.H. Hwang, H.I. Jung, Optimization of electrohydrodynamic writing technique to print collagen, Exp. Tech. 31 (2007) 15-19. doi:10.1111/j.1747-1567.2007.00154.x.

[71] V.L. Workman, L.B. Tezera, P.T. Elkington, S.N. Jayasinghe, Controlled generation of microspheres incorporating extracellular matrix fibrils for three-dimensional cell culture, Adv. Funct. Mater. 24 (2014) 2648-2657. doi:10.1002/adfm.201303891.

[72] S.N. Jayasinghe, Bio-electrosprays: the development of a promising tool for regenerative and therapeutic medicine, Biotechnol. J. 2 (2007) 934-7. doi:10.1002/biot.200700063.

[73] U. Demirci, Acoustic picoliter droplets for emerging applications in semiconductor industry and biotechnology, J. Microelectromechanical Syst. 15 (2006) 957-966. doi:10.1109/JMEMS.2006.878879.

[74] S. Moon, S.K. Hasan, Y.S. Song, F. Xu, H.O. Keles, F. Manzur, et al., Layer by layer threedimensional tissue epitaxy by cell-laden hydrogel droplets., Tissue Eng. Part C. Methods. 16 (2010) 157-66. doi:10.1089/ten.TEC.2009.0179.

[75] A.M. Worthington, On the Forms Assumed by Drops of Liquids Falling Vertically on a Horizontal Plate, Proc. R. Soc. London . 25 (1876) 261-272. doi:10.1098/rspl.1876.0048.

[76] Y. Son, C. Kim, D.H. Yang, D.J. Ahn, Spreading of an Inkjet Droplet on a Solid Surface with a Controlled Contact Angle at Low Weber and Reynolds Numbers, Langmuir. 24 (2008) 2900-2907. doi:10.1021/la702504v.

[77] J. Stringer, B. Derby, Limits to feature size and resolution in ink jet printing, J. Eur. Ceram. Soc. 29 (2009) 913-918. doi:10.1016/j.jeurceramsoc.2008.07.016.

[78] R. Rioboo, M. Marengo, C. Tropea, Time evolution of liquid drop impact onto solid, dry surfaces, Exp. Fluids. 33 (2002) 112-124. doi:10.1007/s00348-002-0431-x.

[79] I. V Roisman, R. Rioboo, C. Tropea, Normal impact of a liquid drop on a dry surface: model for spreading and receding, Proc. R. Soc. London A Math. Phys. Eng. Sci. 458 (2002) 1411-1430.

[80] R.E. Saunders, B. Derby, Inkjet printing biomaterials for tissue engineering: bioprinting, Int. Mater. Rev. 59 (2014) 430-448. doi:10.1179/1743280414Y.0000000040.

[81] S. Schiaffino, A.A. Sonin, Molten droplet deposition and solidification at low Weber numbers, Phys. Fluids. 9 (1997) 3172. doi:10.1063/1.869434.

[82] C.L. Herran, Y. Huang, Alginate Microsphere Fabrication Using Bipolar Wave-Based Dropon-Demand Jetting., J. Manuf. Process. 14 (2012) 98-106. doi:10.1016/j.jmapro.2011.11.001. 
[83] K. Nakamura, Makoto, Nishiyama, Yuichi, Henmi, Chizuka, Iwanaga, Shintaroh, Nakagawa, Hidemoto, Yamaguchi, Kumiko, Akita, Keiichi, Mochizuki, Shuichi, Takiura, Ink Jet Three-Dimensional Digital Fabrication for Biological Tissue Manufacturing : Analysis of Alginate Microgel Beads Produced by Ink Jet Droplets for Three, J. Imaging Sci. Technol. 52 (2008) 1-6. doi:10.2352.

[84] D. Soltman, V. Subramanian, Inkjet-Printed Line Morphologies and Temperature Control of the Coffee Ring Effect, Langmuir. 24 (2008) 2224-2231. doi:10.1021/la7026847.

[85] S. Schiaffino, A. Sonin, On the theory for the arrest of an advancing molten contact line on a cold solid of the same material, Phys. Fluids. 9 (1997) 2227. doi:10.1063/1.869345.

[86] N.F. Morrison, O.G. Harlen, Viscoelasticity in inkjet printing, Rheol. Acta. 49 (2010) 619632. doi:10.1007/s00397-009-0419-z.

[87] W. Lee, J. Pinckney, V. Lee, J.-H. Lee, K. Fischer, S. Polio, et al., Three-dimensional bioprinting of rat embryonic neural cells, Neuroreport. 20 (2009) 798-803. doi:10.1097/WNR.0b013e32832b8be4.

[88] A. Blandino, M. Macías, D. Cantero, Formation of calcium alginate gel capsules: influence of sodium alginate and $\mathrm{CaCl} 2$ concentration on gelation kinetics, J. Biosci. Bioeng. 88 (1999) 686-9. doi:10.1016/S1389-1723(00)87103-0.

[89] A. Blaeser, D.F. Duarte Campos, M. Weber, S. Neuss, B. Theek, H. Fischer, et al., Biofabrication under fluorocarbon: a novel freeform fabrication technique to generate high aspect ratio tissue-engineered constructs, Biores. Open Access. 2 (2013) 374-84. doi:10.1089/biores.2013.0031.

[90] J.Y. Park, J.-C. Choi, J.-H. Shim, J.-S. Lee, H. Park, S.W. Kim, et al., A comparative study on collagen type I and hyaluronic acid dependent cell behavior for osteochondral tissue bioprinting, Biofabrication. 6 (2014) 035004. doi:10.1088/1758-5082/6/3/035004.

[91] E.A. Roth, T. Xu, M. Das, C. Gregory, J.J. Hickman, T. Boland, Inkjet printing for highthroughput cell patterning, Biomaterials. 25 (2004) 3707-15. doi:10.1016/j.biomaterials.2003.10.052.

[92] M. Yanez, J. Rincon, A. Dones, C. De Maria, R. Gonzales, T. Boland, In vivo assessment of printed microvasculature in a bilayer skin graft to treat full-thickness wounds, Tissue Eng. Part A. 21 (2015) 224-33. doi:10.1089/ten.TEA.2013.0561.

[93] A. Skardal, D. Mack, E. Kapetanovic, A. Atala, J.D. Jackson, J. Yoo, et al., Bioprinted amniotic fluid-derived stem cells accelerate healing of large skin wounds, Stem Cells Transl. Med. 1 (2012) 792-802. doi:10.5966/sctm.2012-0088.

[94] J.W. Nichol, S.T. Koshy, H. Bae, C.M. Hwang, S. Yamanlar, A. Khademhosseini, Cell-laden microengineered gelatin methacrylate hydrogels, Biomaterials. 31 (2010) 5536-44. doi:10.1016/j.biomaterials.2010.03.064.

[95] J.A. Benton, C.A. DeForest, V. Vivekanandan, K.S. Anseth, Photocrosslinking of gelatin macromers to synthesize porous hydrogels that promote valvular interstitial cell 
[96] C.B. Hutson, J.W. Nichol, H. Aubin, H. Bae, S. Yamanlar, S. Al-Haque, et al., Synthesis and characterization of tunable poly(ethylene glycol): gelatin methacrylate composite hydrogels, Tissue Eng. Part A. 17 (2011) 1713-23. doi:10.1089/ten.TEA.2010.0666.

[97] S. Zalipsky, J.M. Harris, Introduction to chemistry and biological applications of poly(ethylene glycol), in: S. Zalipsky, J.M. Harris (Eds.), Poly(ethylene Glycol) Chem. Biol. Appl., 1st ed., American Chemical Society, 1997: pp. 1-13. doi:10.1021/bk-19970680.ch001.

[98] G. Gao, T. Yonezawa, K. Hubbell, G. Dai, X. Cui, Inkjet-bioprinted acrylated peptides and PEG hydrogel with human mesenchymal stem cells promote robust bone and cartilage formation with minimal printhead clogging, Biotechnol. J. 10 (2015) 1568-77. doi:10.1002/biot.201400635.

[99] X. Cui, K. Breitenkamp, M. Lotz, D. D'Lima, Synergistic action of fibroblast growth factor-2 and transforming growth factor-beta1 enhances bioprinted human neocartilage formation, Biotechnol. Bioeng. 109 (2012) 2357-68. doi:10.1002/bit.24488.

[100] G. Gao, A.F. Schilling, T. Yonezawa, J. Wang, G. Dai, X. Cui, Bioactive nanoparticles stimulate bone tissue formation in bioprinted three-dimensional scaffold and human mesenchymal stem cells, Biotechnol. J. 9 (2014) 1304-11. doi:10.1002/biot.201400305.

[101] J. a Phillippi, E. Miller, L. Weiss, J. Huard, A. Waggoner, P. Campbell, Microenvironments engineered by inkjet bioprinting spatially direct adult stem cells toward muscle- and bone-like subpopulations, Stem Cells. 26 (2008) 127-34. doi:10.1634/stemcells.20070520.

[102] S. Ilkhanizadeh, A.I. Teixeira, O. Hermanson, Inkjet printing of macromolecules on hydrogels to steer neural stem cell differentiation, Biomaterials. 28 (2007) 3936-43. doi:10.1016/j.biomaterials.2007.05.018.

[103] X. Tang, M. Yakut Ali, M.T. a. Saif, A novel technique for micro-patterning proteins and cells on polyacrylamide gels, Soft Matter. 8 (2012) 7197. doi:10.1039/c2sm25533b.

[104] H. Kerdjoudj, F. Boulmedais, N. Berthelemy, H. Mjahed, H. Louis, P. Schaaf, et al., Cellularized alginate sheets for blood vessel reconstruction, Soft Matter. 7 (2011) 3621. doi:10.1039/c0sm00998a.

[105] A. Skardal, J. Zhang, L. McCoard, X. Xu, S. Oottamasathien, G.D. Prestwich, Photocrosslinkable hyaluronan-gelatin hydrogels for two-step bioprinting, Tissue Eng. Part A. 16 (2010) 2675-85. doi:10.1089/ten.TEA.2009.0798.

[106] K. Jakab, C. Norotte, B. Damon, F. Marga, A. Neagu, C.L. Besch-Williford, et al., Tissue engineering by self-assembly of cells printed into topologically defined structures, Tissue Eng. Part A. 14 (2008) 413-21. doi:10.1089/tea.2007.0173.

[107] R. Gaetani, P.A. Doevendans, C.H.G. Metz, J. Alblas, E. Messina, A. Giacomello, et al., Cardiac tissue engineering using tissue printing technology and human cardiac progenitor 
[108] L.A. Hockaday, K.H. Kang, N.W. Colangelo, P.Y.C. Cheung, B. Duan, E. Malone, et al., Rapid 3D printing of anatomically accurate and mechanically heterogeneous aortic valve hydrogel scaffolds, Biofabrication. 4 (2012) 035005. doi:10.1088/1758-5082/4/3/035005.

[109] C.M. Owens, F. Marga, G. Forgacs, C.M. Heesch, Biofabrication and testing of a fully cellular nerve graft, Biofabrication. 5 (2013) 045007. doi:10.1088/17585082/5/4/045007.

[110] S. Khalil, J. Nam, W. Sun, Multi-nozzle deposition for construction of 3D biopolymer tissue scaffolds, Rapid Prototyp. J. 11 (2005) 9-17. doi:10.1108/13552540510573347.

[111] N.E. Fedorovich, J.R. De Wijn, A.J. Verbout, J. Alblas, W.J.A. Dhert, Three-dimensional fiber deposition of cell-laden, viable, patterned constructs for bone tissue printing, Tissue Eng. Part A. 14 (2008) 127-33. doi:10.1089/ten.a.2007.0158.

[112] I.T. Ozbolat, H. Chen, Y. Yu, Development of "Multi-arm Bioprinter" for hybrid biofabrication of tissue engineering constructs, Robot. Comput. Integr. Manuf. 30 (2014) 295-304. doi:10.1016/j.rcim.2013.10.005.

[113] G. Marchioli, L. van Gurp, P.P. van Krieken, D. Stamatialis, M. Engelse, C.A. van Blitterswijk, et al., Fabrication of three-dimensional bioplotted hydrogel scaffolds for islets of Langerhans transplantation, Biofabrication. 7 (2015) 025009. doi:10.1088/1758$5090 / 7 / 2 / 025009$.

[114] Y. Yu, Y. Zhang, I.T. Ozbolat, A hybrid bioprinting approach for scale-up tissue fabrication, J. Manuf. Sci. Eng. 136 (2014) 061013. doi:10.1115/1.4028511.

[115] J.E. Snyder, Q. Hamid, C. Wang, R. Chang, K. Emami, H. Wu, et al., Bioprinting cell-laden matrigel for radioprotection study of liver by pro-drug conversion in a dual-tissue microfluidic chip, Biofabrication. 3 (2011) 034112. doi:10.1088/1758-5082/3/3/034112.

[116] K. Markstedt, A. Mantas, I. Tournier, H. Martínez Ávila, D. Hägg, P. Gatenholm, 3D bioprinting human chondrocytes with nanocellulose-alginate bioink for cartilage tissue engineering applications, Biomacromolecules. 16 (2015) 1489-96. doi:10.1021/acs.biomac.5b00188.

[117] R. Chang, J. Nam, W. Sun, Direct cell writing of 3D microorgan for in vitro pharmacokinetic model, Tissue Eng. Part C. Methods. 14 (2008) 157-66. doi:10.1089/ten.tec.2007.0392.

[118] R. Chang, K. Emami, H. Wu, W. Sun, Biofabrication of a three-dimensional liver microorgan as an in vitro drug metabolism model, Biofabrication. 2 (2010) 045004. doi:10.1088/1758-5082/2/4/045004.

[119] K. Salonitis, Stereolithography, in: S. Hashmi, E. Bayraktar, G. Batalha, D. Brabazon, M. Buggy, I.A. Choudhury, et al. (Eds.), Compr. Mater. Process., Elsevier, Oxford, 2014: pp. 19-67. doi:10.1016/B978-0-08-096532-1.01001-3.

[120] H. Lin, D. Zhang, P.G. Alexander, G. Yang, J. Tan, A.W.-M. Cheng, et al., Application of 
visible light-based projection stereolithography for live cell-scaffold fabrication with designed architecture, Biomaterials. 34 (2013) 331-9.

doi:10.1016/j.biomaterials.2012.09.048.

[121] D.J. Odde, M.J. Renn, Laser-guided direct writing of living cells., Biotechnol. Bioeng. 67 (2000) 312-8. http://www.ncbi.nlm.nih.gov/pubmed/10620261.

[122] C. Mézel, A. Souquet, L. Hallo, F. Guillemot, Bioprinting by laser-induced forward transfer for tissue engineering applications: jet formation modeling, Biofabrication. 2 (2010) 014103. doi:10.1088/1758-5082/2/1/014103.

[123] R. Xiong, Z. Zhang, W. Chai, Y. Huang, D.B. Chrisey, Freeform drop-on-demand laser printing of 3D alginate and cellular constructs, Biofabrication. 7 (2015) 045011. doi:10.1088/1758-5090/7/4/045011.

[124] L. Horváth, Y. Umehara, C. Jud, F. Blank, A. Petri-Fink, B. Rothen-Rutishauser, Engineering an in vitro air-blood barrier by 3D bioprinting, Sci. Rep. 5 (2015) 7974. doi:10.1038/srep07974.

[125] X. Cui, G. Gao, T. Yonezawa, G. Dai, Human cartilage tissue fabrication using threedimensional inkjet printing technology, J. Vis. Exp. (2014). doi:10.3791/51294.

[126] V. Mironov, T. Trusk, V. Kasyanov, S. Little, R. Swaja, R. Markwald, Biofabrication: a 21st century manufacturing paradigm, Biofabrication. 1 (2009) 022001. doi:10.1088/17585082/1/2/022001.

[127] A.B. Dababneh, I.T. Ozbolat, Bioprinting technology: a current state-of-the-art review, J. Manuf. Sci. Eng. 136 (2014) 061016. doi:10.1115/1.4028512.

[128] I.T. Ozbolat, W. Peng, V. Ozbolat, Application areas of 3D bioprinting, Drug Discov. Today. 00 (2016)(in press). doi:10.1016/j.drudis.2016.04.006.

[129] V. Lee, G. Singh, J.P. Trasatti, C. Bjornsson, X. Xu, T.N. Tran, et al., Design and fabrication of human skin by three-dimensional bioprinting, Tissue Eng. Part C. Methods. 20 (2014) 473-84. doi:10.1089/ten.TEC.2013.0335.

[130] V.K. Lee, A.M. Lanzi, N. Haygan, S.-S. Yoo, P.A. Vincent, G. Dai, Generation of multi-scale vascular network system within 3D hydrogel using 3D bio-printing technology, Cell. Mol. Bioeng. 7 (2014) 460-472. doi:10.1007/s12195-014-0340-0.

[131] L. Zhao, V.K. Lee, S.-S. Yoo, G. Dai, X. Intes, The integration of 3-D cell printing and mesoscopic fluorescence molecular tomography of vascular constructs within thick hydrogel scaffolds, Biomaterials. 33 (2012) 5325-32. doi:10.1016/j.biomaterials.2012.04.004.

[132] P.G. Campbell, L.E. Weiss, Tissue engineering with the aid of inkjet printers, Expert Opin. Biol. Ther. 7 (2007) 1123-7. doi:10.1517/14712598.7.8.1123.

[133] T. Xu, J. Rohozinski, W. Zhao, E.C. Moorefield, A. Atala, J.J. Yoo, Inkjet-mediated gene transfection into living cells combined with targeted delivery, Tissue Eng. Part A. 15 (2009) 95-101. doi:10.1089/ten.tea.2008.0095. 
[134] D.A. Zopf, S.J. Hollister, M.E. Nelson, R.G. Ohye, G.E. Green, Bioresorbable airway splint created with a three-dimensional printer, N. Engl. J. Med. 368 (2013) 2043-5. doi:10.1056/NEJMc1206319.

[135] F. Xu, J. Wu, S. Wang, N.G. Durmus, U.A. Gurkan, U. Demirci, Microengineering methods for cell-based microarrays and high-throughput drug-screening applications, Biofabrication. 3 (2011) 034101. doi:10.1088/1758-5082/3/3/034101.

[136] F. Xu, S. Moon, A.E. Emre, C. Lien, E.S. Turali, U. Demirci, Cell bioprinting as a potential high-throughput method for fabricating cell-based biosensors (CBBs), in: 2009 IEEE Sensors, IEEE, 2009: pp. 387-391. doi:10.1109/ICSENS.2009.5398245.

[137] W. Peng, U. Derya, I.T. Ozbolat, Bioprinting Towards Physiologically-relevant Tissue Models for Pharmaceutics, Trends Biotechnol. (2016)(in press). doi:10.1016/j.tibtech.2016.05.013.

[138] I.T. Ozbolat, Y. Yu, Bioprinting toward organ fabrication: challenges and future trends, IEEE Trans. Biomed. Eng. 60 (2013) 691-9. doi:10.1109/TBME.2013.2243912.

[139] E. Bianconi, A. Piovesan, F. Facchin, A. Beraudi, R. Casadei, F. Frabetti, et al., An estimation of the number of cells in the human body, Ann. Hum. Biol. 40 (2013) 463-71. doi:10.3109/03014460.2013.807878.

[140] G.M. Cooper, The eukaryotic cell cycle, in: Cell A Mol. Approach, 1st ed., Sinauer Associates, Sunderland, 2000. http://www.ncbi.nlm.nih.gov/books/NBK9876/.

[141] A. Bruce, A. Johnson, J. Lewis, M. Raff, K. Roberts, P. Walter, An overview of the cell cycle, in: Mol. Biol. Cell, 4th ed., Garland Science, New York, 2002. http://www.ncbi.nlm.nih.gov/books/NBK26869/.

[142] A.J. Engler, S. Sen, H.L. Sweeney, D.E. Discher, Matrix elasticity directs stem cell lineage specification, Cell. 126 (2006) 677-89. doi:10.1016/j.cell.2006.06.044.

[143] J. McCormack, Anti-Hypertensives to Prevent Death, Heart Attacks, and Strokes, (2014). http://www.thennt.com/nnt/anti-hypertensives-to-prevent-death-heart-attacks-andstrokes/ (accessed January 1, 2016).

[144] D. Newman, Statins for Heart Disease Prevention (Without Prior Heart Disease), (2015). http://www.thennt.com/nnt/statins-for-heart-disease-prevention-without-prior-heartdisease/ (accessed January 1, 2016).

[145] L.M. Friedman, C.D. Furberg, D.L. DeMets, Introduction to clinical trials, in: Fundam. Clin. Trials, 4th ed., Springer New York, New York, NY, 2010: pp. 1-18. doi:10.1007/978-14419-1586-3.

[146] R. Barrangou, L.A. Marraffini, CRISPR-Cas systems: Prokaryotes upgrade to adaptive immunity, Mol. Cell. 54 (2014) 234-44. doi:10.1016/j.molcel.2014.03.011.

[147] P.D. Hsu, E.S. Lander, F. Zhang, Development and applications of CRISPR-Cas9 for genome engineering, Cell. 157 (2014) 1262-1278. doi:10.1016/j.cell.2014.05.010. 
[148] J.T. Hinson, A. Chopra, N. Nafissi, W.J. Polacheck, C.C. Benson, S. Swist, et al., Titin mutations in iPS cells define sarcomere insufficiency as a cause of dilated cardiomyopathy, Science. 349 (2015) 982-6. doi:10.1126/science.aaa5458.

[149] J. Liu, C. Gao, W. Chen, W. Ma, X. Li, Y. Shi, et al., CRISPR/Cas9 facilitates investigation of neural circuit disease using human iPSCs: mechanism of epilepsy caused by an SCN1A loss-of-function mutation, Transl. Psychiatry. 6 (2016) e703. doi:10.1038/tp.2015.203.

[150] W.S. Choi, D. Ha, S. Park, T. Kim, Synthetic multicellular cell-to-cell communication in inkjet printed bacterial cell systems, Biomaterials. 32 (2011) 2500-7. doi:10.1016/j.biomaterials.2010.12.014.

[151] M. Nakamura, Y. Nishiyama, C. Henmi, 3D Micro-fabrication by Inkjet 3D biofabrication for 3D tissue engineering, in: 2008 Int. Symp. Micro-NanoMechatronics Hum. Sci., IEEE, 2008: pp. 451-456. doi:10.1109/MHS.2008.4752495.

[152] P.G. Campbell, E.D. Miller, G.W. Fisher, L.M. Walker, L.E. Weiss, Engineered spatial patterns of FGF-2 immobilized on fibrin direct cell organization, Biomaterials. 26 (2005) 6762-70. doi:10.1016/j.biomaterials.2005.04.032.

[153] E.D. Miller, G.W. Fisher, L.E. Weiss, L.M. Walker, P.G. Campbell, Dose-dependent cell growth in response to concentration modulated patterns of FGF-2 printed on fibrin, Biomaterials. 27 (2006) 2213-21. doi:10.1016/j.biomaterials.2005.10.021.

[154] C.J. Ferris, K.J. Gilmore, S. Beirne, D. McCallum, G.G. Wallace, M. in het Panhuis, Bio-ink for on-demand printing of living cells, Biomater. Sci. 1 (2013) 224-230. doi:10.1039/C2BM00114D.

[155] N. Mongkoldhumrongkul, S. Best, E. Aarons, S.N. Jayasinghe, Bio-electrospraying whole human blood: analysing cellular viability at a molecular level, J. Tissue Eng. Regen. Med. 3 (2009) 562-6. doi:10.1002/term.185.

[156] J. Xie, C.-H. Wang, Electrospray in the dripping mode for cell microencapsulation, J. Colloid Interface Sci. 312 (2007) 247-55. doi:10.1016/j.jcis.2007.04.023.

[157] C. Li, A. Faulkner-Jones, A.R. Dun, J. Jin, P. Chen, Y. Xing, et al., Rapid formation of a supramolecular polypeptide-DNA hydrogel for in situ three-dimensional multilayer bioprinting, Angew. Chem. Int. Ed. Engl. 54 (2015) 3957-61. doi:10.1002/anie.201411383.

[158] C.L. Herran, N. Coutris, Drop-on-demand for aqueous solutions of sodium alginate, Exp. Fluids. 54 (2013). doi:10.1007/s00348-013-1548-9.

[159] U. Demirci, G. Montesano, Cell encapsulating droplet vitrification, Lab Chip. 7 (2007) 1428-33. doi:10.1039/b705809h.

[160] F. Zou, N. Zhao, X. Fu, J. Diao, Y. Ma, X. Cao, et al., Enhanced osteogenic differentiation and biomineralization in mouse mesenchymal stromal cells on a $\beta$-TCP robocast scaffold modified with collagen nanofibers, RSC Adv. 6 (2016) 23588-23598. doi:10.1039/C5RA26670J. 
[161] J.-H. Shim, J.-S. Lee, J.Y. Kim, D.-W. Cho, Bioprinting of a mechanically enhanced threedimensional dual cell-laden construct for osteochondral tissue engineering using a multihead tissue/organ building system, J. Micromechanics Microengineering. 22 (2012) 085014. doi:10.1088/0960-1317/22/8/085014.

[162] B. Duan, L.A. Hockaday, K.H. Kang, J.T. Butcher, 3D Bioprinting of heterogeneous aortic valve conduits with alginate/gelatin hydrogels, J. Biomed. Mater. Res. Part A. 101A (2013) 1255-1264. doi:10.1002/jbm.a.34420.

[163] F. Pati, J. Jang, D.-H. Ha, S. Won Kim, J.-W. Rhie, J.-H. Shim, et al., Printing threedimensional tissue analogues with decellularized extracellular matrix bioink, Nat Commun. 5 (2014).

[164] C.M. Smith, A. Stone, R.L. Stewart, M.W. Simpkins, A.M. Kachurin, D. Ph, et al., ThreeDimensional BioAssembly Tool for Generating Viable Tissue-Engineered Constructs, Tissue Eng. 10 (2004) 1566-1576.

[165] L. Koch, A. Deiwick, S. Schlie, S. Michael, M. Gruene, V. Coger, et al., Skin tissue generation by laser cell printing, Biotechnol. Bioeng. 109 (2012) 1855-1863. doi:10.1002/bit.24455.

[166] L.E. Bertassoni, M. Cecconi, V. Manoharan, M. Nikkhah, J. Hjortnaes, A.L. Cristino, et al., Hydrogel bioprinted microchannel networks for vascularization of tissue engineering constructs, Lab Chip. 14 (2014) 2202-2211. doi:10.1039/C4LC00030G.

[167] D. Kolesky, R. Truby, A.S. Gladman, T. Busbee, K. Homan, J. Lewis, Bioprinting: 3D Bioprinting of Vascularized, Heterogeneous Cell-Laden Tissue Constructs (Adv. Mater. 19/2014), Adv. Mater. 26 (2014) 2966. doi:10.1002/adma.201470124. 
Figure 1: Classification of droplet-based bioprinting into inkjet, acoustic, and micro-valve bioprinting modalities. Inkjet bioprinting is further classified into continuous inkjet, drop-on-demand and electrohydrodynamic jetting modalities. Drop-on-demand inkjet bioprinting comprises thermal, piezoelectric and electrostatic techniques.

Figure 2: Mechanisms of droplet-based bioprinting. (A) Inkjet bioprinting techniques: (A1) continuousink-jetting relies on Rayleigh-Plateau instability, which breaks bioink jets into droplets; (A2) thermal drop-on-demand bioprinting employs a thermal actuator to locally heat bioink solutions to generate droplets; (A3) piezoelectric drop-on-demand bioprinting depends on radial deformation of a piezoelectric actuator to generate droplets; (A4) electrostatic bioprinting relies on deflection of pressure 
plate to generate droplets; (A5) electrohydrodynamic jetting uses an electric field, resulting from the electric potential difference between the printhead and the substrate, to pull a stream of bioink droplets through the printhead orifice. (B) Acoustic-droplet ejection relies on a gentle acoustic field generated by an acoustic actuator to eject droplets from an open pool of bioink solution. (C) Micro-valve (solenoid) bioprinting operates with an electromechanical valve to dispense droplets.

Figure 3: Droplet-based bioprinting of cells and biologics. Thermal DOD bioprinting of neurons tagged with neuronal markers after 15 days of culture, (A1) immunostaining of dendrites of rat embryonic cortical neurons with MAP2 monoclonal antibodies (green), (A2) immunostaining of dendrites of rat embryonic hippocampal with anti-MAP2 monoclonal antibodies (green) and axons of the neurons with anti-neurofilament monoclonal antibodies (red) (reproduced/adapted with permission from Ref. [54]); (B) TIJ bioprinting of 3D cardiac tissue (reproduced/adapted with permission from Ref. [57]); (C) PIJ bioprinting of tissue constructs (NIH $3 \mathrm{~T} 3$ cells with sodium alginate) with bifurcations (reproduced/adapted with permission from Ref. [60]); (D) Electrostatic bioprinting of alginate tubular construct (reproduced/adapted with permission from Ref. [31]); (E) Electrohydrodynamic jet bioprinting of PVSMCs at 40 days post bioprinting (reproduced/adapted with permission from Ref. [72]); (F) Acoustic bioprinting of AML-12 cells at 12 days post bioprinting (reproduced/adapted with permission from Ref. [23]); Micro-valve bioprinting of fibroblasts and keratinocytes, (G1) immunostained 3D image of the cells and its side views, (G2) keratin layer of $K C,(G 3) \beta$-tubulin of keratinocytes and fibroblasts (reproduced/adapted with permission from Ref. [46]).

Figure 4: Droplet-substrate interactions and fabrication of 3D constructs through layer-by-layer deposition. (A) Droplets of a cell-laden hydrogel precursor solution are deposited at specific locations on the lateral plane by controlling the movement of the printhead and/or the substrate. The deposited droplets spread and coalesce to from lines on the substrate. The coalesced lines in turn assemble to 
form the first layer of the desired 3D pattern, which is subsequently polymerized by depositing the droplets of crosslinking (ionic or enzymatic) solution. This cycle is repeated until the fabrication of the entire construct is completed. (B) Alternatively, each layer of the bioprinted hydrogel precursor solution is polymerized by lowering the substrate into a reservoir of the crosslinker and raising it again before a new layer is bioprinted. (C) Each layer of the bioprinted hydrogel precursor solution is polymerized by spraying the crosslinking solution. (D) Each layer of the bioprinted hydrogel precursor solution (photocurable bioink) is polymerized using UV-light.

Figure 5: Recent achievements in droplet-based bioprinting. (A1) 3D liver tissue model (top view) comprising of 40 layers of bioprinted alginate and HLCs acquired through differentiation of hiPSCs and hESCs and the side view (A2) (reproduced/adapted with permission from Ref. [32]); (B1) 3D heterogeneous tissue model consisting of bioprinted dSMCs (red) labeled with PKH 67 dye, hAFSCs (blue) labeled with CMHC dye, and bECs (green) labeled with PKH 26 dye which retained their functionality and the differentiation capacity both in vitro and in vivo, (B2) vascularization of the bECs constructs eight weeks after implantation (reproduced/adapted with permission from Ref. [17]); Bioprinted 3D cartilage tissue transplants (C1) maintained their biological functions both in vitro and in vivo, (C2) cartilage tissue construct fabrication by layer-by-layer deposition of chondrocytes-fibrinogencollagen into a previously electrospun layer of PCL fibers (reproduced/adapted with permission from Ref. [35]); (D) Angiogenesis of vascular sprouts validated by immunostaining at day 14 (reproduced/adapted with permission from Ref. [130]); (E1) A high-throughput drug screening platform fabricated by bioprinting a layer of agar and bacteria on a glass slide followed by bioprinting of a second layer of alginate which is subsequently crosslinked by bioprinting of a third layer of $\mathrm{CaCal}_{2}$ with antibiotics, (E2) light-microscopy and (E3) fluorescence imaging of the bioprinted samples (reproduced/adapted with permission from Ref. [38]); (F) A 3D ovarian cancer model fabricated by 
simultaneously bioprinting cancer cells (OVCAR-5) and fibroblasts (MRC-5) on a Matrigel ${ }^{\mathrm{TM}}$-coated glass bottom culture dish. 


\begin{tabular}{|c|c|c|c|c|}
\hline Mechanism & Type & Bioprinter & University/Company & Use \\
\hline \multirow{5}{*}{ 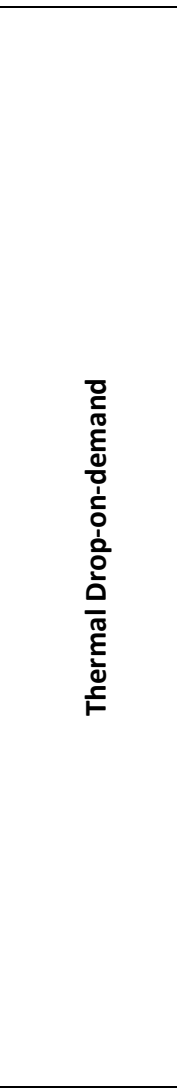 } & \multirow{5}{*}{ 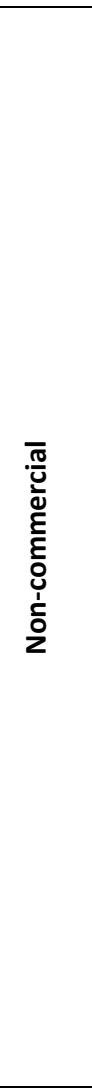 } & $\begin{array}{l}\text { Modified Canon Bubble Jet printer (BJC- } \\
\text { 2100) and modified Hewlett-Packard } \\
\text { Deskjet printers (HP 550C, HP 500, and } \\
\text { HP 340) }\end{array}$ & $\begin{array}{l}\text { Clemson University and The } \\
\text { University of Texas at El Paso }\end{array}$ & $\begin{array}{l}\text { Collagen scaffolding patterns [91], mammalian cell (CHO cells and rat } \\
\text { primary embryonic motoneural cells) constructs [21], neural cell (rat } \\
\text { hippocampal and cortical cell) constructs [54], alginate 3D constructs } \\
\text { [30], cardiac 3D constructs (feline and H1 cardiomyocytes with } \\
\text { alginate), vascular (HMVECs and Fibrin) constructs [52], skin } \\
\text { transplants (NHDF and NHEK) with built-in vascular networks } \\
\text { (HMVECs) for in-vivo wound healing studies [92] }\end{array}$ \\
\hline & & $\begin{array}{l}\text { Modified Hewlett-Packard Deskjet } \\
\text { printer (HP 550C) }\end{array}$ & Wake Forest University & $\begin{array}{l}\text { Alginate microspheres with single-encapsulated-cells (beta-TC6) [55], } \\
\text { complex heterogeneous 3D tissue models with hAFCS, dSMCs, and } \\
\text { bECs [17] }\end{array}$ \\
\hline & & $\begin{array}{l}\text { Modified Hewlett-Packard Deskjet } \\
\text { printer (HP 500) }\end{array}$ & $\begin{array}{l}\text { The Scripps Research } \\
\text { Institute }\end{array}$ & $\begin{array}{l}\text { In-situ bioprinting of chondrocytes and PEGDMA hydrogel for direct } \\
\text { cartilage repair [56], cartilage constructs (human articular } \\
\text { chondrocytes) to study FGF- } 2 \text { and TGF- } \beta 1 \text { growth factors impact on } \\
\text { printed cartilage formation [99] }\end{array}$ \\
\hline & & $\begin{array}{l}\text { Modified Hewlett-Packard Deskjet } \\
\text { printer }\end{array}$ & $\begin{array}{l}\text { Stemorgan Therapeutics, } \\
\text { Technical University Munich, } \\
\text { The Scripps Research } \\
\text { Institute, Tokyo University of } \\
\text { Science, Rensselaer } \\
\text { Polytechnic Institute, Wuhan } \\
\text { University of Technology }\end{array}$ & $\begin{array}{l}\text { Stem cell tissue constructs (hMSCs with PEG) and their directed } \\
\text { differentiation into bone and cartilage }[98,100]\end{array}$ \\
\hline & & Modified Hewlett-Packard 5360 printer & $\begin{array}{l}\text { University of Texas at El } \\
\text { Paso, Shanghai Jiao Tong } \\
\text { University, Sun Yat-sen } \\
\text { University, and Texas Tech } \\
\text { University Health Sciences } \\
\end{array}$ & $\begin{array}{l}\text { High-throughput miniature drug-screening platform employing } \\
\text { bioprinted E. coli-laden alginate and three different antibiotics } \\
\text { (penicillin/streptomycin, antimycotic, and kanamycin sulfate) [38] }\end{array}$ \\
\hline \multirow{2}{*}{ 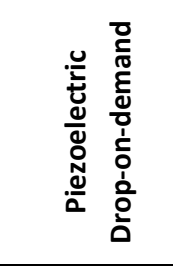 } & \multirow{2}{*}{ 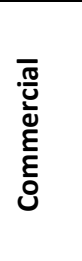 } & Fujifilm Dimatrix (DMP-2800) printer & $\begin{array}{l}\text { Ulsan National Institute of } \\
\text { Science and Technology } \\
\text { (UNIST) }\end{array}$ & Bacterial cells to study cell-to-cell communications [150] \\
\hline & & Cluster Technology DeskViewer $^{\mathrm{TM}}$ & $\begin{array}{l}\text { Osaka University and Japan } \\
\text { Science and Technology } \\
\text { Agency (JST) }\end{array}$ & $\begin{array}{l}\text { Human liver tissue chips comprising of hepatocytes (HepG2) and } \\
\text { HUVECs [9] }\end{array}$ \\
\hline
\end{tabular}

Table 1 


\begin{tabular}{|c|c|c|c|c|}
\hline & & MicroFab JetLab II & $\begin{array}{l}\text { Georgia Institute of } \\
\text { Technology and Tufts } \\
\text { University }\end{array}$ & Silk nest arrays for hosting cells (E.coli) for biosensing [39] \\
\hline & \multirow{9}{*}{ 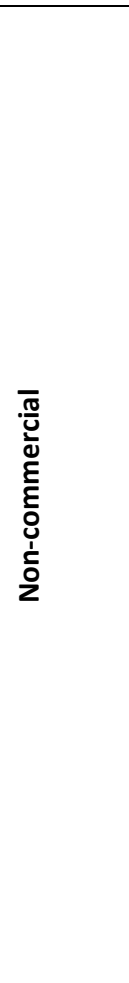 } & $\begin{array}{l}\text { Modified Hewlett-Packard (HP 660C) } \\
\text { printer with add-on piezoelectric pump }\end{array}$ & Clemson University & $\begin{array}{l}\text { Protein (bovine serum albumin and streptavidin) and cell (bovine } \\
\text { aortal endothelial cell) 2D constructs [29] }\end{array}$ \\
\hline & & $\begin{array}{l}\text { Custom printer with Fuji piezoelectric } \\
\text { print head (Fuji Electric systems) }\end{array}$ & $\begin{array}{l}\text { University of Toyama and } \\
\text { Kanagawa Academy of } \\
\text { Science and Technology }\end{array}$ & $\begin{array}{l}\text { Hydrogel (alginate) tubular constructs [151], 3D tissue (HeLa cells and } \\
\text { alginate) constructs [59] }\end{array}$ \\
\hline & & Custom Printer & $\begin{array}{l}\text { University of Freiburg, Trinity } \\
\text { College, and Women and } \\
\text { Infants University Hospital }\end{array}$ & Microspheres with single-encapsulated-cells (HeLa cells)[64] \\
\hline & & $\begin{array}{l}\text { Custom printer with single nozzle } \\
\text { piezoelectric printhead }\end{array}$ & $\begin{array}{l}\text { Tokyo University and Osaka } \\
\text { University }\end{array}$ & $\begin{array}{l}\text { Microspheres with single-encapsulated-cells (SF9 insect cells) and to } \\
\text { compare pull-push and push-pull piezoelectric actuation mechanisms } \\
\text { [62] }\end{array}$ \\
\hline & & $\begin{array}{l}\text { Custom printer with MicroFab MJ-ABP- } \\
01 \text { piezoelectric nozzle }\end{array}$ & $\begin{array}{l}\text { University of British } \\
\text { Columbia }\end{array}$ & $\begin{array}{l}\text { MCF-7 movement within in the nozzle during the printing process } \\
\text { [63] }\end{array}$ \\
\hline & & $\begin{array}{l}\text { Custom printer with MicroFab MJ-ABL- } \\
01-120-6 \mathrm{MX} \text { piezoelectric nozzle }\end{array}$ & $\begin{array}{l}\text { Clemson University and } \\
\text { University of Florida }\end{array}$ & $\begin{array}{l}\text { Complex tubular tissue (NIH 3T3 cells and alginate) constructs with } \\
\text { bifurcations }[11,60]\end{array}$ \\
\hline & & $\begin{array}{l}\text { Custom printer with Microdrop } \\
\text { Technologies piezoelectric Microdrop } \\
\text { Nozzle }\end{array}$ & $\begin{array}{l}\text { Swiss Federal Institute of } \\
\text { Technology Lausanne }\end{array}$ & $\begin{array}{l}\text { Microvasculatures with viable cells (NIH 3T3 fibroblasts) and their } \\
\text { stability against physiological flows [61] }\end{array}$ \\
\hline & & $\begin{array}{l}\text { Custom printer with MicroJet } \\
\text { piezoelectric actuator with MicroFab } \\
\text { Technologies nozzle }\end{array}$ & $\begin{array}{l}\text { Carnegie Mellon University } \\
\text { and University of Pittsburgh } \\
\text { Medical Center (UPMC) }\end{array}$ & $\begin{array}{l}\text { FGF-2 dose impact on human MG-63 osteosarcoma cell response } \\
{[152,153], B M P-2 \text { to evaluate spatially controlled differentiation of }} \\
\text { MDSCs [101] }\end{array}$ \\
\hline & & $\begin{array}{l}\text { Custom printer with Xaar-126 } \\
\text { piezoelectric print head }\end{array}$ & University of Wollongong & 2D tissue (C2C12 and PC12 cells) constructs [154] \\
\hline 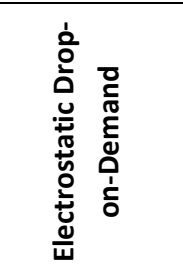 & 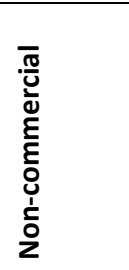 & $\begin{array}{l}\text { Custom printer with Epson SEA-Jet } \\
\text { printhead }\end{array}$ & $\begin{array}{l}\text { University of Toyama and } \\
\text { Kanagawa Academy of } \\
\text { Science and Technology }\end{array}$ & 3D tissue (HeLa cells) constructs (hollow tubes) [31] \\
\hline 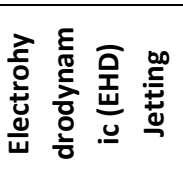 & 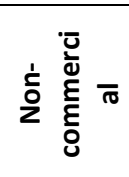 & $\begin{array}{l}\text { Custom printer EHD printer using } \\
\text { commercially available subsystems }\end{array}$ & University of London & $\begin{array}{l}\text { EHD as a viable bioprinting strategy using Jurkat cells [41], CAD } \\
\text { (Cath.-a-differentiated) mouse neural cells [22], human astrocytoma } \\
\text { cells [69], white blood cells, erythrocytes [155], and THP-1 cells with } \\
\text { alginate and collagen [71] }\end{array}$ \\
\hline
\end{tabular}




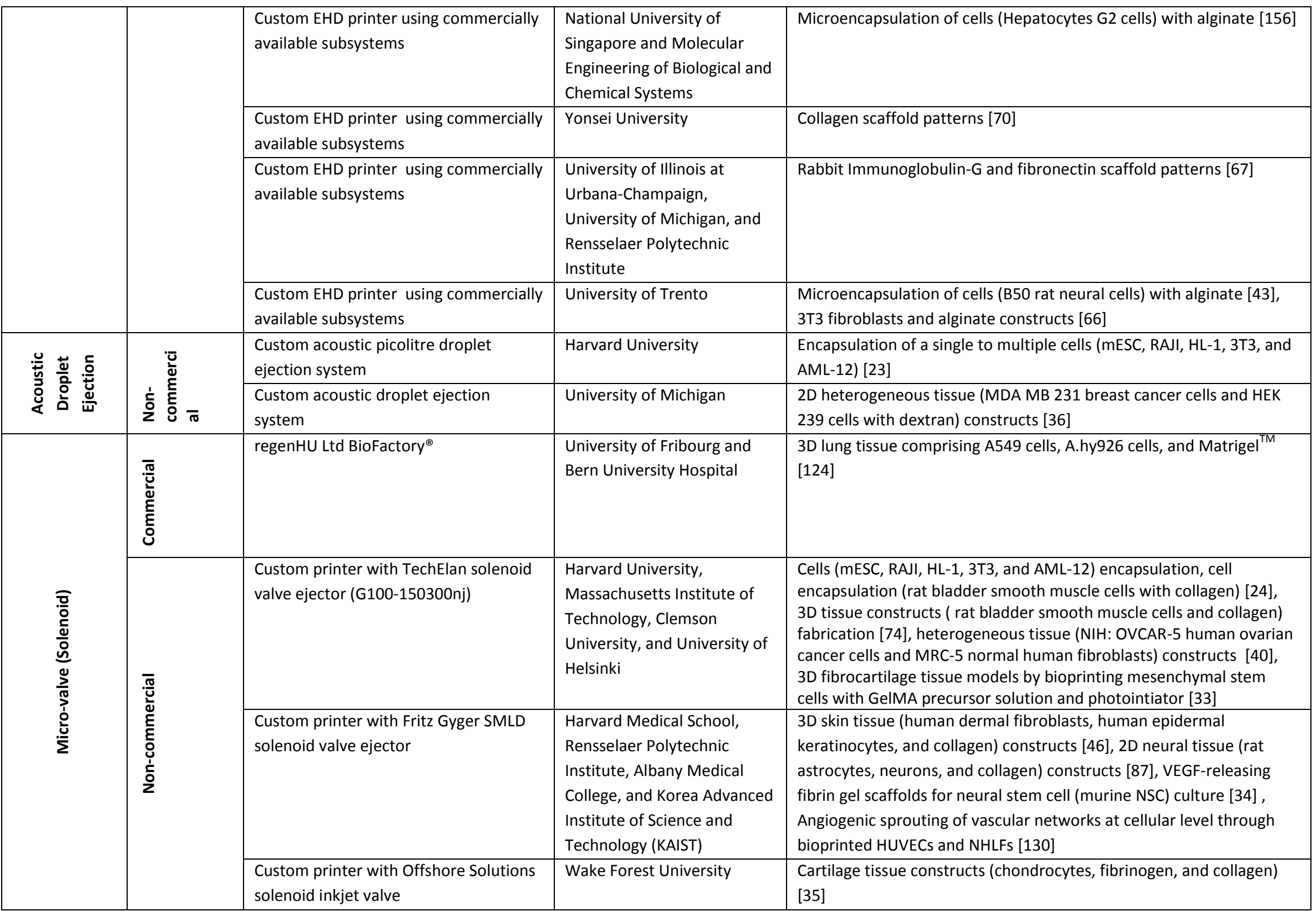


Tissue (HEK293 and hESC cells) spheroids [45], 3D hepatocyte

Nanolitre Dispense valve with Lee

Roslin Biocentre

constructs (HLCs differentiated from hESCs and hiPSCs with alginate)

Products Minstac Nozzle

Custom printer

[32], DNA based hydrogel bioprinting [157]

8
9

10

11

12

13

14

15

16

18

19

21

23

24

25

26

28

29

30

31

32

33

34

35

36

38

39

40

41

42

43

44

45

46

47 


\begin{tabular}{|c|c|c|c|c|c|c|c|c|c|}
\hline \multirow{2}{*}{$\begin{array}{c}\text { DBB } \\
\text { Modality }\end{array}$} & \multirow{2}{*}{$\begin{array}{l}\text { Nozzle } \\
\text { Size }\end{array}$} & \multirow{2}{*}{$\begin{array}{l}\text { Droplet } \\
\text { Diameter }\end{array}$} & \multirow{2}{*}{$\begin{array}{c}\text { Cell } \\
\text { Viability }\end{array}$} & \multicolumn{3}{|c|}{ Bioink Printability } & \multirow{2}{*}{$\begin{array}{l}\text { Operating } \\
\text { Conditions }\end{array}$} & \multirow[t]{2}{*}{ Advantages } & \multirow[t]{2}{*}{ Disadvantages } \\
\hline & & & & Material & $\begin{array}{c}\text { Maximum } \\
\text { concentration } \\
(w / v)\end{array}$ & $\begin{array}{l}\text { Maximum } \\
\text { viscosity } \\
\text { (mPA.s) }\end{array}$ & & & \\
\hline \multirow[t]{4}{*}{$\begin{array}{l}\text { Thermal } \\
\text { DOD }\end{array}$} & \multirow[t]{4}{*}{$\begin{array}{l}50 \mu \mathrm{m} \\
{[54]}\end{array}$} & \multirow[t]{4}{*}{$\begin{array}{l}30-60 \mu \mathrm{m} \\
{[54,55]}\end{array}$} & \multirow[t]{4}{*}{$\begin{array}{l}75-90 \% \\
{[17,21,56,9} \\
8-100]\end{array}$} & $\begin{array}{l}\text { Alginate } \\
\text { (NaAlg) } \\
{[30,55,57]}\end{array}$ & $\begin{array}{l}2.3 \% \\
{[30,55,57]}\end{array}$ & N/A & \multirow{4}{*}{$\begin{array}{l}10^{5}-10^{7} \text { cells/ml } \\
{[17,21,56,98-} \\
100] \text { exposed to } \\
200-300^{\circ} \mathrm{C} \text { for } \\
\text { few milliseconds } \\
\text { (ms) }[91]\end{array}$} & \multirow[t]{4}{*}{$\begin{array}{l}\text { Low cost, ideal for } \\
\text { feasibility studies }\end{array}$} & \multirow{4}{*}{$\begin{array}{l}\text { Limited cell types and } \\
\text { clogging issues owing to } \\
\text { smaller nozzle diameter, } \\
\text { thermal and mechanical } \\
\text { stress on cells during droplet } \\
\text { ejection, difficult to clean as } \\
\text { cartridges are designed for } \\
\text { 2D paper printing, limited } \\
\text { range of orifice diameters } \\
\text { and not available in single } \\
\text { nozzle configuration }\end{array}$} \\
\hline & & & & PEG [98] & $10 \%[98]$ & $1.85[98]$ & & & \\
\hline & & & & $\begin{array}{l}\text { PEG- } \\
\text { GeIMA } \\
{[98]}\end{array}$ & $\begin{array}{l}\text { 10\% PEG and } \\
5 \% \text { GelMa } \\
{[98]}\end{array}$ & 4 [98] & & & \\
\hline & & & & $\begin{array}{l}\text { Thrombin } \\
{[52]}\end{array}$ & $\begin{array}{l}200 \text { unit/ml } \\
{[52]}\end{array}$ & $\mathrm{N} / \mathrm{A}$ & & & \\
\hline $\begin{array}{l}\text { Piezoelectric } \\
\text { DOD }\end{array}$ & $\begin{array}{l}21.5- \\
120 \mu \mathrm{m} \\
{[11,60,} \\
63,150]\end{array}$ & $\begin{array}{l}50-100 \mu \mathrm{m} \\
{[11,63,82,15} \\
0]\end{array}$ & $\begin{array}{l}70-95 \% \\
{[9,11,29,60} \\
]\end{array}$ & $\begin{array}{l}\text { Alginate } \\
\text { (NaAlg } \\
\text { from } \\
\text { Sigma- } \\
\text { Aldrich) } \\
{[11,158]}\end{array}$ & $2 \%[11,158]$ & $\begin{array}{l}140\left(n_{0}\right) \\
{[11,158]}\end{array}$ & $\begin{array}{l}10^{5}-10^{7} \text { cells } / \mathrm{ml} \\
{[9,11,29,60]}\end{array}$ & $\begin{array}{l}\text { Control over } \\
\text { droplet generation } \\
\text { and placement, } \\
\text { wide range of } \\
\text { nozzle diameters, } \\
\text { available in single } \\
\text { nozzle } \\
\text { configuration, } \\
\text { cleanable as long as } \\
\text { bioinks are not } \\
\text { dried out }\end{array}$ & $\begin{array}{l}\text { Nozzle clogging, satellite } \\
\text { droplets, mechanical stress } \\
\text { on cells during droplet } \\
\text { ejection, made of glass } \\
\text { which is not suitable for } \\
\text { certain bioinks such as } \\
\text { fibrinogen }\end{array}$ \\
\hline $\begin{array}{l}\text { Electrostatic } \\
\text { DOD }\end{array}$ & $\mathrm{n} / \mathrm{a}$ & $\begin{array}{l}10-60 \mu \mathrm{m} \\
{[31]}\end{array}$ & $70 \%[31]$ & $\begin{array}{l}\text { Alginate } \\
{[31]}\end{array}$ & $1 \%[31]$ & $10[31]$ & $\begin{array}{l}10^{6}-10^{7} \text { cells } / \mathrm{ml} \\
{[31]}\end{array}$ & $\begin{array}{l}\text { Low cost, ideal for } \\
\text { feasibility studies }\end{array}$ & $\begin{array}{l}\text { Limited cell types and } \\
\text { clogging issues owing to } \\
\text { smaller nozzle diameter, } \\
\text { mechanical stress on cells } \\
\text { during droplet ejection, } \\
\text { difficult to clean as } \\
\text { cartridges are designed for } \\
\text { 2D paper printing, limited } \\
\text { range of orifice diameters } \\
\text { and not available in single } \\
\text { nozzle configuration }\end{array}$ \\
\hline $\begin{array}{l}\text { Electrohydro } \\
\text { dynamic }\end{array}$ & $\begin{array}{l}2- \\
1000\end{array}$ & $\begin{array}{l}5-2000 \mu \mathrm{m} \\
{[43,66,67,69}\end{array}$ & $\begin{array}{l}>90 \% \\
{[66,71,156]}\end{array}$ & $\begin{array}{l}\text { Alginate } \\
\text { (NaAlg }\end{array}$ & $2 \%[71]$ & $>2000[71]$ & $\begin{array}{l}\text { Applied voltage } \\
\text { of } 0.250 \text { to } 20 \mathrm{kV}\end{array}$ & $\begin{array}{l}\text { Droplets smaller } \\
\text { than nozzle orifice }\end{array}$ & $\begin{array}{l}\text { Expensive, unavailability of } \\
\text { commercial complete }\end{array}$ \\
\hline
\end{tabular}




\begin{tabular}{|c|c|c|c|c|c|c|c|c|c|}
\hline \multirow[t]{2}{*}{ jetting } & \multirow[t]{2}{*}{$\begin{array}{l}\mu \mathrm{m} \\
{[43,66,} \\
67,69- \\
71,156]\end{array}$} & \multirow[t]{2}{*}{$-71,156]$} & & $\begin{array}{l}\text { from } \\
\text { Sigma- } \\
\text { Aldrich) } \\
{[71]} \\
\end{array}$ & & & \multirow{2}{*}{$\begin{array}{l}{[43,66,67,69-} \\
71,156], \text { flow rate } \\
\text { of } 10^{-10} \mathrm{~m}^{3} / \mathrm{s} \\
(0.36 \mathrm{~mL} / \mathrm{h}) \text { to } 10^{-} \\
{ }^{8} \mathrm{~m}^{3} / \mathrm{s}(36 \mathrm{~mL} / \mathrm{h}) \\
{[43,66,67,69-} \\
71,156], 10^{6} \text { to } \\
10^{7} \text { cells } / \mathrm{ml} \\
{[43,66,67,69-} \\
71,156]\end{array}$} & \multirow{2}{*}{$\begin{array}{l}\text { diameter, low } \\
\text { mechanical stress } \\
\text { on cells during } \\
\text { droplets ejection, } \\
\text { viscous bioinks are } \\
\text { dispensable }\end{array}$} & \multirow[t]{2}{*}{$\begin{array}{l}\text { systems, unsafe for } \\
\text { operators, not capable of } \\
\text { ejecting single droplet at a } \\
\text { time }\end{array}$} \\
\hline & & & & $\begin{array}{l}\text { Collagen } \\
\text { [70] }\end{array}$ & $\begin{array}{l}3 \% \text { in } 3 \% \\
\text { acetic acid } \\
{[70]}\end{array}$ & $\mathrm{N} / \mathrm{A}$ & & & \\
\hline $\begin{array}{l}\text { Acoustic } \\
\text { bioprinting }\end{array}$ & $n / a$ & $\begin{array}{l}5-300 \mu \mathrm{m} \\
{[23,36]}\end{array}$ & $\begin{array}{l}>90 \% \\
{[23,36]}\end{array}$ & $\begin{array}{l}\text { Ethylene } \\
\text { glycol [23] }\end{array}$ & N/A & 18 [23] & $\begin{array}{l}10^{5} \text { to } 10^{7} \\
\text { cells } / \mathrm{ml}[23,36]\end{array}$ & $\begin{array}{l}\text { No mechanical } \\
\text { stress on cells } \\
\text { during droplet } \\
\text { ejection, easy to } \\
\text { fabricate }\end{array}$ & $\begin{array}{l}\text { Viscous bioinks are not } \\
\text { dispensable, unavailability of } \\
\text { commercial complete } \\
\text { systems, }\end{array}$ \\
\hline \multirow[t]{3}{*}{$\begin{array}{l}\text { Micro-valve } \\
\text { bioprinting }\end{array}$} & \multirow{3}{*}{$\begin{array}{l}100- \\
300 \mu \mathrm{m} \\
{[45,46} \\
124]\end{array}$} & \multirow[t]{3}{*}{$\begin{array}{l}100-600 \\
{[45,46,124]}\end{array}$} & \multirow{3}{*}{$\begin{array}{l}>90 \% \\
{[24,32,33,4} \\
0,45,46,74, \\
87,154,159 \\
]\end{array}$} & $\begin{array}{l}\text { Collagen } \\
\text { type I } \\
{[131]}\end{array}$ & $0.9 \%$ [131] & $\mathrm{N} / \mathrm{A}$ & \multirow{3}{*}{$\begin{array}{l}10^{5} \text { to } 10^{7} \\
\text { cells/ml } \\
{[24,32,33,40,45,4} \\
6,74,87,154,159]\end{array}$} & \multirow{3}{*}{$\begin{array}{l}\text { Low cost, viscous } \\
\text { bioinks are } \\
\text { dispensable, } \\
\text { cleanable as long as } \\
\text { bioinks are not } \\
\text { dried out, } \\
\text { interchangeable } \\
\text { nozzles }\end{array}$} & \multirow{3}{*}{$\begin{array}{l}\text { Significantly larger droplet } \\
\text { diameters than nozzle orifice } \\
\text { diameter, greater shear } \\
\text { stress on cells during droplet } \\
\text { ejection as nozzles are not } \\
\text { available in tapered } \\
\text { configuration }\end{array}$} \\
\hline & & & & $\begin{array}{l}\text { Fibrinogen } \\
{[34]}\end{array}$ & $6.2 \%[34]$ & $\mathrm{N} / \mathrm{A}$ & & & \\
\hline & & & & $\begin{array}{l}\text { Thrombin } \\
\text { [34] }\end{array}$ & $\begin{array}{l}133 \text { unit/ml } \\
\text { [34] }\end{array}$ & $\mathrm{N} / \mathrm{A}$ & & & \\
\hline
\end{tabular}

N/A - Information is not available

$\eta_{0}-$ Zero-shear viscosity 
Table 3

\begin{tabular}{|c|c|c|c|c|c|c|c|}
\hline Bioink & $\begin{array}{l}\text { Crosslinking } \\
\text { mechanism }\end{array}$ & Concentration & Cell types bioprinted & $\begin{array}{c}\text { DBB } \\
\text { modality }\end{array}$ & Applications & Advantages & Disadvantages \\
\hline 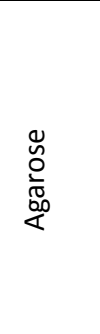 & Thermal [89] & $3 \% \mathrm{w} / \mathrm{v}[89]$ & MG-63 [89] & $\begin{array}{l}\text { Mechanical } \\
\text { valve } \\
\text { (plunger)- } \\
\text { based DOD } \\
\text { [89] }\end{array}$ & Vascular tissue [89] & $\begin{array}{l}\text { High mechanical } \\
\text { strength, protein } \\
\text { adsorption } \\
\text { resistance, low } \\
\text { cost, } \\
\text { nonimmunogenic }\end{array}$ & $\begin{array}{l}\text { Low cell } \\
\text { adhesion, fragile, } \\
\text { require } \\
\text { incorporation of } \\
\text { temperature } \\
\text { controlling } \\
\text { mechanism for } \\
\text { DBB }\end{array}$ \\
\hline 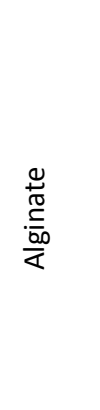 & Ionic crosslinking & $\begin{array}{c}3 \% \mathrm{w} / \mathrm{v} \text { [89]; } 10 \mathrm{mg} / \mathrm{ml} \text { with } 3 \\
\mathrm{mg} / \mathrm{ml} \text { Collagen type I [17]; } 1.5 \% \\
\text { w/v [32]; } 1 \% \mathrm{w} / \mathrm{v} \text { [60] }\end{array}$ & $\begin{array}{c}\text { MG-63 [89]; hAFSCs, } \\
\text { dSMCs and bECs }\left(2-3 \times 10^{6}\right. \\
\text { cells } / \mathrm{ml}) \text { with } 0.1 \mathrm{M} \mathrm{CaCl}_{2} \\
\text { [17]; hiPSCs }\left(1 \times 10^{7}\right. \\
\text { cells } / \mathrm{ml})[32] ; 3 \mathrm{T3} \text { mouse } \\
\text { fibroblasts }\left(5 \times 10^{6}\right. \\
\text { cells } / \mathrm{ml})[60]\end{array}$ & $\begin{array}{c}\text { Mechanical } \\
\text { valve } \\
\text { (plunger)- } \\
\text { based DOD } \\
\text { [89], TIJ } \\
\text { [17]; } \\
\text { Micro-valve } \\
\text { [32]; PIJ } \\
\text { [60] }\end{array}$ & $\begin{array}{l}\text { Vascular tissue [89], In-vitro and in- } \\
\text { vivo evaluation of stem cells } \\
\text { functionality and differentiation } \\
\text { [17]; Liver tissue [32]; Cellular tubes } \\
\text { with bifurcations to demonstrate } \\
\text { vascular tissue fabrication [60] }\end{array}$ & $\begin{array}{c}\text { Biocompatibility, } \\
\text { good } \\
\text { bioprintability at } \\
\text { low } \\
\text { concentrations, } \\
\text { fast gelation, } \\
\text { medium } \\
\text { elasticity, low } \\
\text { cost, } \\
\text { nonimmunogenic }\end{array}$ & $\begin{array}{c}\text { Absence of } \\
\text { motifs for cell } \\
\text { attachment, } \\
\text { nozzle clogging at } \\
\text { high } \\
\text { concentrations }\end{array}$ \\
\hline
\end{tabular}




\begin{tabular}{|c|c|c|c|c|c|c|c|}
\hline $\begin{array}{l}\overline{0} \\
\sum_{1}^{2} \\
\overline{0} \\
0 \\
00 \\
\frac{0}{0} \\
0\end{array}$ & $\begin{array}{l}\text { Thermal, pH [34] } \\
\text { Chemical: use of a } \\
\text { chemical crosslinker } \\
\text { such as genipin, } \\
\text { glutaraldehyde etc. }\end{array}$ & $\begin{array}{c}1.16 \mathrm{mg} / \mathrm{ml}[34] ; 1 \mathrm{mg} / \mathrm{ml}[91] ; 3.2 \\
\mathrm{mg} / \mathrm{ml}[92] ; 6-9 \mathrm{mg} / \mathrm{ml}[131] ; 2.2 \\
\mathrm{mg} / \mathrm{ml} \text { mixed with } 50 \mathrm{mg} / \mathrm{ml} \\
\text { fibrinogen in } 1: 1 \text { ratio [93]; } 1.5 \\
\mathrm{mg} / \mathrm{ml} \text { with } 10 \mathrm{mg} / \mathrm{ml} \text { fibrinogen } \\
\text { [35]; } 3 \mathrm{mg} / \mathrm{ml}[129]\end{array}$ & $\begin{array}{c}\text { AFSCs and } \\
\text { MSCs }\left(1.66 \times 10^{7} \text { cells } / \mathrm{ml}\right) \\
{[93] ; \text { Rabbit elastic }} \\
\text { chondrocytes }\left(3-4 \times 10^{6}\right. \\
\text { cells } / \mathrm{ml})[35] ;\end{array}$ & $\begin{array}{l}\text { Micro-valve } \\
\text { [34]; TIJ } \\
\text { [91]; } \\
\text { Micro-valve } \\
{[35,93,129} \\
131]\end{array}$ & $\begin{array}{l}\text { Scaffold (enclosure) for bioprinted } \\
\text { NSCs and VEGF-containing fibrin } \\
\text { [34]; Protein patterns for } \\
\text { modulating smooth muscle cells } \\
\text { attachment [91]; Pipetted NHEK- or } \\
\text { NHDF-laden collagen interlayers for } \\
\text { skin graft fabrication [92] ; Perfused } \\
\text { vascular structure [131]; } \\
\text { Comparison of AFSCs and MSCs } \\
\text { ability to heal skin wounds [93]; } \\
\text { Cartilage tissue [35]; Collagen } \\
\text { interlayers for skin } \\
\text { tissue(comprising fibroblasts and } \\
\text { keratinocytes) fabrication [129] }\end{array}$ & $\begin{array}{l}\text { Biomimetic, } \\
\text { biocompatible, } \\
\text { promotes cell- } \\
\text { attachment and } \\
\text { proliferation, } \\
\text { signal transducer, } \\
\text { nonimmunogenic }\end{array}$ & $\begin{array}{l}\text { Poor mechanical } \\
\text { strength, slow } \\
\text { gelation, fibrous } \\
\text { and can clog } \\
\text { nozzles easily }\end{array}$ \\
\hline 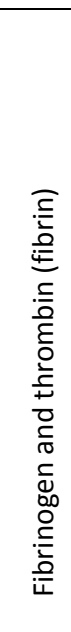 & Enzymatic & $\begin{array}{l}62.8 \mathrm{mg} / \mathrm{ml} \text { fibrinogen and } 133 \\
\mathrm{NIH} \mathrm{U} / \mathrm{ml} \text { of thrombin [34]; } 60 \\
\mathrm{mg} / \mathrm{ml} \text { fibrinogen and } 40 \mathrm{NIH} \mathrm{U} / \mathrm{ml} \\
\text { of cell-laden thrombin [92]; } 20 \\
\mathrm{U} / \mathrm{ml} \text { of thrombin [35] ; } 10 \mathrm{mg} / \mathrm{ml} \\
\text { of manually deposited fibrinogen } \\
\text { and } 20 \mathrm{IU} / \mathrm{ml} \text { of bioprinted } \\
\text { thrombin [54]; } 50 \mathrm{U} / \mathrm{ml} \text { of cell- } \\
\text { laden thrombin bioprinted over } 60 \\
\mathrm{mg} / \mathrm{ml} \mathrm{of} \mathrm{fibrinogen} \mathrm{substrate} \\
{[52] ; 10 \mathrm{mg} / \mathrm{ml} \text { of fibrinogen and } 3} \\
\mathrm{U} / \mathrm{ml} \text { of thrombin [130]; } 0.1 \mathrm{mg} / \mathrm{ml} \\
\text { of fibrinogen plated glass slides } \\
\text { incubated in } 4 \mathrm{U} / \mathrm{ml} \text { of thrombin } \\
\text { for } 2 \mathrm{~h} \text { at } 37^{\circ} \mathrm{C}[101]\end{array}$ & $\begin{array}{l}\text { HMVECs }\left(2 \times 10^{6} \text { cells } / \mathrm{ml}\right) \\
\text { with thrombin }[92] ; \\
\text { HMVECs }\left(1-8 \times 10^{6}\right. \\
\text { cells } / \mathrm{ml})[52] ; \text { NHLFs }(2 \times \\
\left.10^{6} \text { cells } / \mathrm{ml}\right) \text { and GFP- } \\
\text { transfected HUVECs }(1 \times \\
\left.10^{6} \text { cells } / \mathrm{ml}\right) \text { with } \\
\text { fibrinogen and thrombin } \\
{[130]}\end{array}$ & $\begin{array}{c}\text { Micro-valve } \\
{[34,35,92,1} \\
30] ; \text { TIJ } \\
{[52,54]}\end{array}$ & $\begin{array}{l}\text { VEGF delivery for NSCs [34]; } \\
\text { HMVECs-laden fibrin interlayers } \\
\text { (bioprinted cell-laden thrombin and } \\
\text { pipetted fibrinogen) for skin graft } \\
\text { fabrication [92]; Crosslinking of } \\
\text { bioprinted } \\
\text { chondrocytes/fibrinogen/collagen } \\
\text { layers for cartilage tissue fabrication } \\
\text { [35]; Fibrin interlayers for 3D neural } \\
\text { sheet fabrication [54]; Human } \\
\text { microvasculature engineering [52]; } \\
\text { Angiogenic sprouting between two } \\
\text { parallel vascular channels [130]; } \\
\text { Fibrin substrates for bioprinted } \\
\text { BMP-2 patterns [101] }\end{array}$ & $\begin{array}{l}\text { Biomimetic, } \\
\text { biocompatible, } \\
\text { promotes } \\
\text { angiogenesis } \\
\text { (causes } \\
\text { inflammatory } \\
\text { response), fast } \\
\text { gelation, good } \\
\text { integrality, } \\
\text { medium elasticity }\end{array}$ & $\begin{array}{l}\text { Low mechanical } \\
\text { strength, fibrous } \\
\text { and can clog } \\
\text { nozzles easily, } \\
\text { limited DBB } \\
\text { printability }\end{array}$ \\
\hline
\end{tabular}




\begin{tabular}{|c|c|c|c|c|}
\hline $\begin{array}{l}\text { Tissue } \\
\text { Type }\end{array}$ & $\begin{array}{l}\text { Bioprinting } \\
\text { Modality }\end{array}$ & Bioink & Cell Viability and/or Remarks & Construct Dimensions \\
\hline \multirow{5}{*}{$\stackrel{Ð}{\check{D}}$} & PIJ DBB & BMP-2 patterns & $\mathrm{N} / \mathrm{A}$ & $750 \times 750 \mu \mathrm{m} 2 \mathrm{D}$ pattern [101] \\
\hline & TIJ DBB & hMSCs, PEGDMA, and HA nanoparticles & $63-86 \%$ & $\begin{array}{c}\text { Cylindrical construct with } 4 \mathrm{~mm} \text { in diameter and } \\
\text { thickness [100] }\end{array}$ \\
\hline & EBB & $\beta$-TCP scaffolds & $\mathrm{N} / \mathrm{A}$ & $\begin{array}{c}10.0 \mathrm{~mm} \times 10.0 \mathrm{~mm} \times 5.0 \mathrm{~mm} \text { cubic and } \Phi 10.0 \mathrm{~mm} \\
\times 20.0 \mathrm{~mm} \text { cylindrical scaffolds [160] }\end{array}$ \\
\hline & $\begin{array}{l}\text { Pneumatic micro- } \\
\text { EBB }\end{array}$ & Bone marrow stromal cells (BMSCs) & $\begin{array}{l}5-100 \% \text { depending on material } \\
\text { type and incubation period }\end{array}$ & $\begin{array}{l}\text { 4-layered constructs using four different needle } \\
\text { diameters of } 150,180,210 \text { and } 610 \mu \mathrm{m} \text { [111] }\end{array}$ \\
\hline & $\begin{array}{l}\text { Pneumatic micro- } \\
\text { EBB } \\
\end{array}$ & human osteoblasts and chondrocytes & $91-96 \%$ & $\begin{array}{c}\text { Constructs of height } 1 \mathrm{~mm} \text { (10 layers) to } 2 \mathrm{~mm} \text { (20 } \\
\text { layers) [161] }\end{array}$ \\
\hline \multirow{4}{*}{ 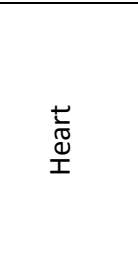 } & TIJ DBB & $\begin{array}{l}\text { Feline cardiomyoctyes, HL1 cardiac muscle } \\
\text { cells and alginate hydrogel precursor }\end{array}$ & $\mathrm{N} / \mathrm{A}$ & $\sim 1.4 \times 1.2 \times 1.5 \mathrm{~cm}$ construct [57] \\
\hline & $\begin{array}{l}\text { Mechanical } \\
\text { micro-EBB }\end{array}$ & $\begin{array}{l}\text { Porcine aortic valve interstitial cells and } \\
\text { human aortic root smooth muscle cells }\end{array}$ & $84 \%$ & $\sim \Phi 3 \mathrm{~cm} \times 3 \mathrm{~cm}$ tall constructs [162] \\
\hline & $\begin{array}{l}\text { Pneumatic micro- } \\
\text { EBB } \\
\end{array}$ & $\begin{array}{l}\text { hASCs and hMSCs with decellularized heart } \\
\text { extracellular matrix }\end{array}$ & $>90 \%$ & $\sim 10 \times 10 \times 5 \mathrm{~mm}$ constructs [163] \\
\hline & Modified LIFT & rat cardiac cells & $\sim 100 \%$ & $50-100 \mu \mathrm{m}$ tall constructs [19] \\
\hline \multirow{5}{*}{ 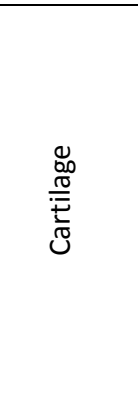 } & Micro-valve DBB & Chondrocytes, fibrinogen, and collagen & $82 \%$ & $7 \times 7 \mathrm{~cm}$ construct with a thickness of $1 \mathrm{~mm}$ [35] \\
\hline & Micro-valve DBB & hMSCs with BMP-2 and TGF- $\beta 1$ & $>90 \%$ & $\begin{array}{l}\text { Single and multilayered square constructs with } \\
\text { dimensions of } 1.5 \times 1.5 \mathrm{~cm}[33]\end{array}$ \\
\hline & TIJ DBB & $\begin{array}{l}\text { human articular chondrocytes within } \\
\text { PEGDMA }\end{array}$ & $89 \%$ & $\begin{array}{l}\text { Bioprinting constructs into } 5 \mathrm{~mm} \text { diameter and 2-5 } \\
\text { mm deep defects [56] }\end{array}$ \\
\hline & $\begin{array}{l}\text { Pneumatic micro- } \\
\text { EBB }\end{array}$ & human chondrocytes & $73-86 \%$ & $\begin{array}{l}4.8 \times 4.8 \times 1 \mathrm{~mm} \text { construct with a line spacing of } 1.2 \\
\mathrm{~mm}[116]\end{array}$ \\
\hline & $\begin{array}{l}\text { Pneumatic micro- } \\
\text { EBB }\end{array}$ & $\begin{array}{c}\text { hASCs and hMSCs with decellularized } \\
\text { cartilage extracellular matrix supported by } \\
\text { PCL framework }\end{array}$ & $>90 \%$ & $\sim 5 \times 5 \times 5 \mathrm{~mm}$ construct [163] \\
\hline \multirow{2}{*}{$\stackrel{\grave{d}}{\stackrel{亠}{ב}}$} & PIJ DBB & $\begin{array}{c}\text { Hepatocytes, endothelial cells, fibronectin, } \\
\text { and gelatin }\end{array}$ & $\sim 100 \%$ & $\begin{array}{l}\text { Single-layer to three-layer tissue models }(\sim 3 \times 3 \mathrm{~cm}) \\
{[9]}\end{array}$ \\
\hline & Micro-valve DBB & $\begin{array}{l}\text { hiPSCs and hESCs directed differentiation } \\
\text { towards hepatocytes }\end{array}$ & $60-90 \%$ & $\begin{array}{l}\text { Ring constructs of dimensions } 4 \mathrm{~mm} \text { in diameter } \\
\text { and } 1 \mathrm{~mm} \text { in height [32] }\end{array}$ \\
\hline$\stackrel{\infty}{5}$ & Micro-valve DBB & $\begin{array}{l}\text { Alveolar epithelial type II cells, endothelial } \\
\text { cells, and Matrigel }^{\text {TM }}\end{array}$ & $86-95 \%$ & $\begin{array}{l}\text { Three distinct layers of the two cell types and the } \\
\text { gel layer separating consisting of } 1.4 \times 10^{5} \text { cells } / \mathrm{cm}^{2}\end{array}$ \\
\hline 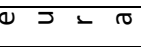 & Micro-valve DBB & Collagen precursor and rat embryonic & $78 \%$ & A $3 \mathrm{~mm}$ diameter ring pattern and a ' $x$ ' pattern \\
\hline
\end{tabular}

Table 4 


\begin{tabular}{|c|c|c|c|c|}
\hline & & $\begin{array}{l}\text { neurons, and collagen precursor and } \\
\text { astrocytes with rat embryonic neurons }\end{array}$ & & comprising two $6 \mathrm{~mm}$ long orthogonal lines [87] \\
\hline & Micro-valve DBB & Neural stem cells with VEGF & $93 \%$ & $\begin{array}{c}\text { A single layer of }(3 \times 2 \mathrm{~mm}) \text { NSCs and an adjacent } \\
\text { circular layer }(5 \mathrm{~mm} \text { diameter) of fibrin comprising } \\
\text { VEGF which were sandwiched between two layers } \\
\text { of collagen ( } 14 \times 14 \mathrm{~mm} \text { sheets) [34] }\end{array}$ \\
\hline \multirow{5}{*}{$\frac{f}{v}$} & Micro-valve DBB & Collagen, fibroblasts and keratinocytes & $84-98 \%$ & $6 \times 6 \times 1.2 \mathrm{~mm}$ constructs [129] \\
\hline & TIJ DBB & $\begin{array}{l}\text { HMVECs with thrombin bioprinted on } \\
\text { previously pipetted collagen-NHDF layer }\end{array}$ & $\begin{array}{c}\text { Faster skin wound healing with } \\
\text { bioprinted grafts as opposed to } \\
\text { without grafts }\end{array}$ & $\begin{array}{l}\text { Grafts of dimensions } 2.5 \times 5 \mathrm{~cm} \text { with a thickness of } \\
1.2 \mathrm{~mm} \text { [92] }\end{array}$ \\
\hline & Micro-valve DBB & $\begin{array}{l}\text { Alternating layers of thrombin, and AFSCs- } \\
\text { and MSCs-laden fibrinogen }\end{array}$ & $\begin{array}{c}\text { AFSCs comparable to MSCs in } \\
\text { skin regeneration and in-situ } \\
\text { bioprinting enabled wound } \\
\text { healing process }\end{array}$ & Constructs in $2.0 \times 2.0 \mathrm{~cm}$ surgical skin wounds [93] \\
\hline & $\begin{array}{l}\text { Pneumatic micro- } \\
\text { EBB }\end{array}$ & $\begin{array}{l}\text { Human fibroblasts suspended in } \\
\text { polyoxyethylene/polyoxypropylene }\end{array}$ & $60 \%$ & $\begin{array}{c}\text { Monolayer constructs extruded with a nozzle of } 350 \\
\mu \mathrm{m} \text { inner diameter [164] }\end{array}$ \\
\hline & Modified LIFT & $\begin{array}{c}\text { NIH-3T3 fibroblasts, human keratinocyte cells } \\
\text { and collagen }\end{array}$ & $\begin{array}{l}\text { Tissue formation verified by } \\
\text { existence of cell-cell junctions }\end{array}$ & $10 \times 10 \times 2 \mathrm{~mm}[165]$ \\
\hline \multirow{4}{*}{ 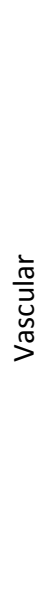 } & Micro-valve DBB & $\begin{array}{c}\text { NHLFs and GFP-transfected HUVECs with } \\
\text { firbrinogen which was crosslinked with } \\
\text { thrombin }\end{array}$ & $\begin{array}{c}\text { Angiogenic sprouting of } \\
\text { endothelial cells between two } \\
\text { parallel vascular fluidic channels } \\
\text { within a collagen construct }\end{array}$ & $\begin{array}{l}\text { Vascular fluidic channels of diameter } \sim 1 \text { and } \\
\text { collagen construct of dimensions } 14 \times 12 \times 4 \mathrm{~mm} \\
\qquad[130]\end{array}$ \\
\hline & $\begin{array}{l}\text { Mechanical } \\
\text { micro-EBB }\end{array}$ & $\begin{array}{l}\text { Human umbilical vein endothelial cells seeded } \\
\text { onto vascular channels fabricated out of } \\
\text { GelMA, star poly(ethylene glycol-co-lactide) } \\
\text { acrylate (SPELA), PEGDMA or PEGDA by using } \\
\text { bioprinted agarose template fibers }\end{array}$ & $\begin{array}{l}\text { Improved mass transport, cell } \\
\text { viability and differentiation } \\
\text { within tissue constructs }\end{array}$ & $\begin{array}{l}\text { Agarose template fibers with } 250 \mu \mathrm{m} \text { inner } \\
\text { diameter [166] }\end{array}$ \\
\hline & $\begin{array}{l}\text { Mechanical or } \\
\text { pneumatic EBB }\end{array}$ & $\begin{array}{l}\text { Human umbilical vein smooth muscle cells } \\
\text { and fibroblasts cells with sodium alginate }\end{array}$ & $75-87 \%$ & $\begin{array}{c}\text { Vasculatures of variable geometry, length, and } \\
\text { orientation which are limited only by tissue strand } \\
\text { diameter and thus the aggregation technique and } \\
\text { oxygen diffusion [114] }\end{array}$ \\
\hline & $\begin{array}{l}\text { Pneumatic micro- } \\
\text { EBB }\end{array}$ & $\begin{array}{c}\text { Human neonatal dermal fibroblast cells and } \\
\text { human umbilical vein endothelial cells with } \\
\text { Pluronic F127 and GelMA }\end{array}$ & $61-82 \%$ & Channels of $100 \mu \mathrm{m}-1 \mathrm{~mm}$ diameter [167] \\
\hline
\end{tabular}

\section{N/A - Information not available}

DBB - Droplet-based bioprinting

EBB - Extrusion-based bioprinting

LIFT - Laser-induced forward transfer 


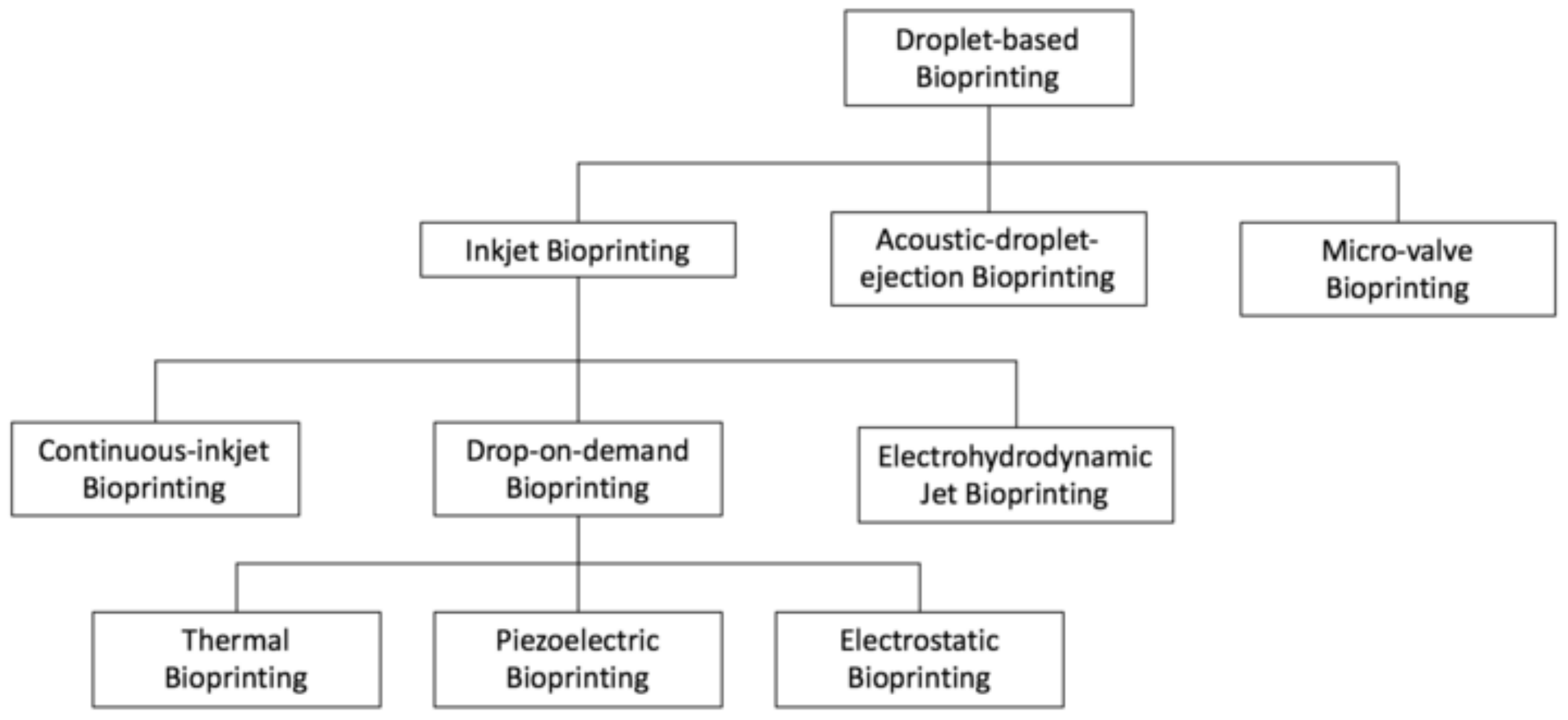


A1

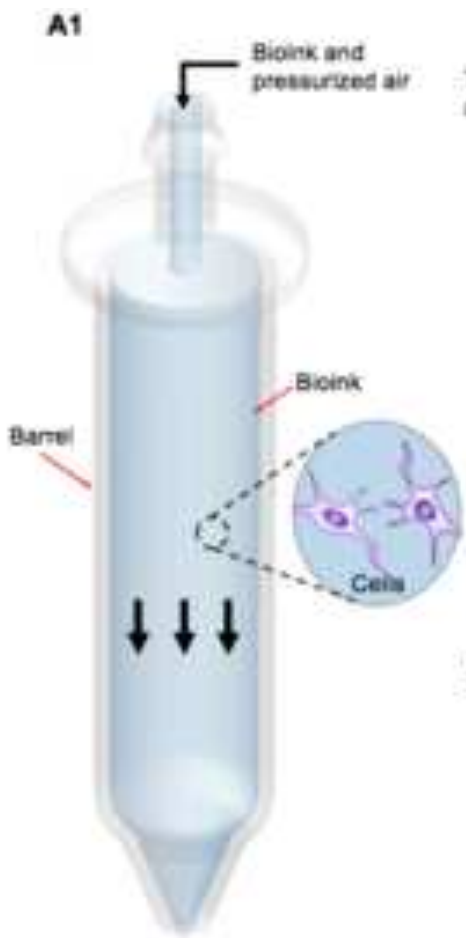

Comtnuove ink jetting
A2

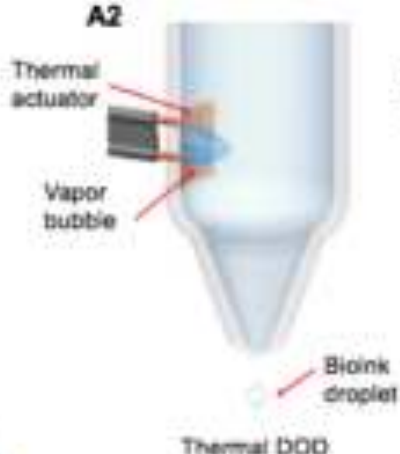

A4

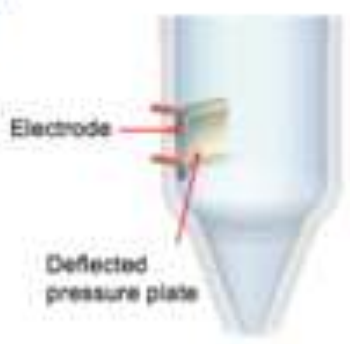

Electrostate DOO

Themal DOO

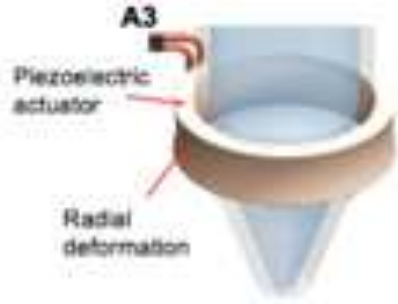

Piesselectile DOC

A5

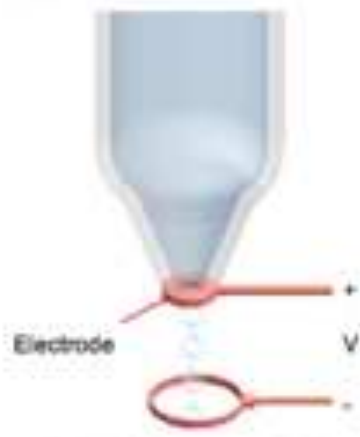

Electrohydrodynamis intting

B
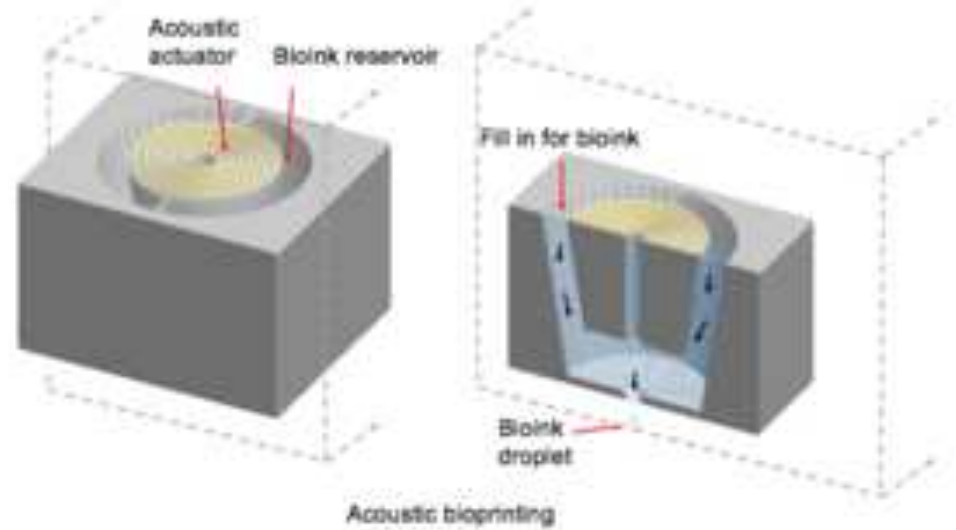

C

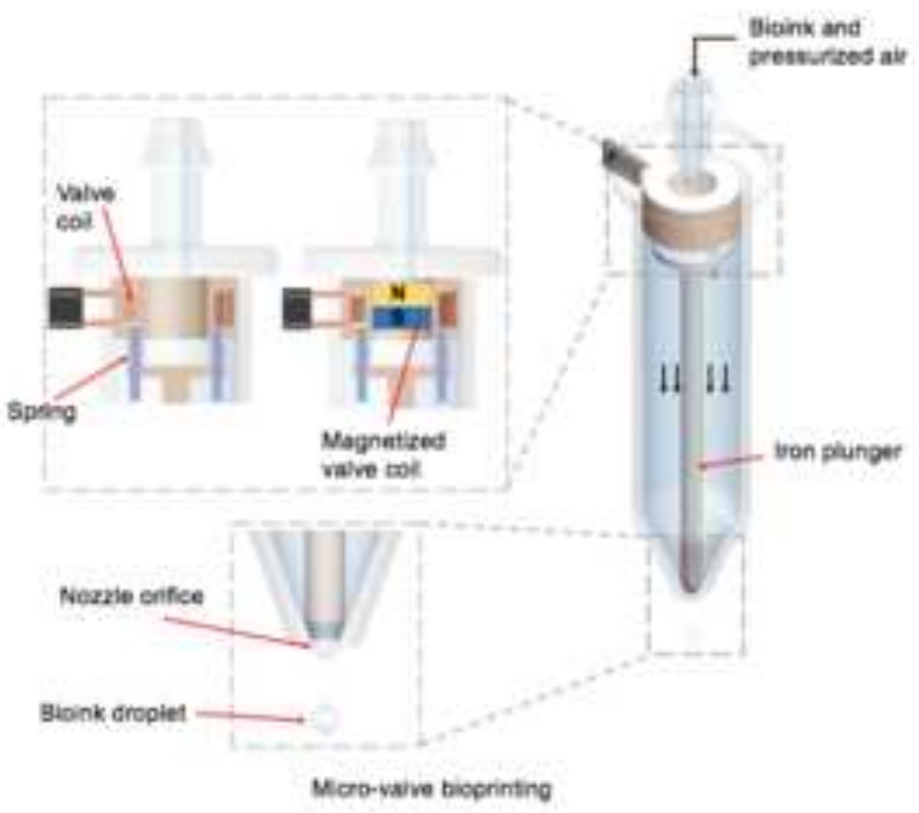



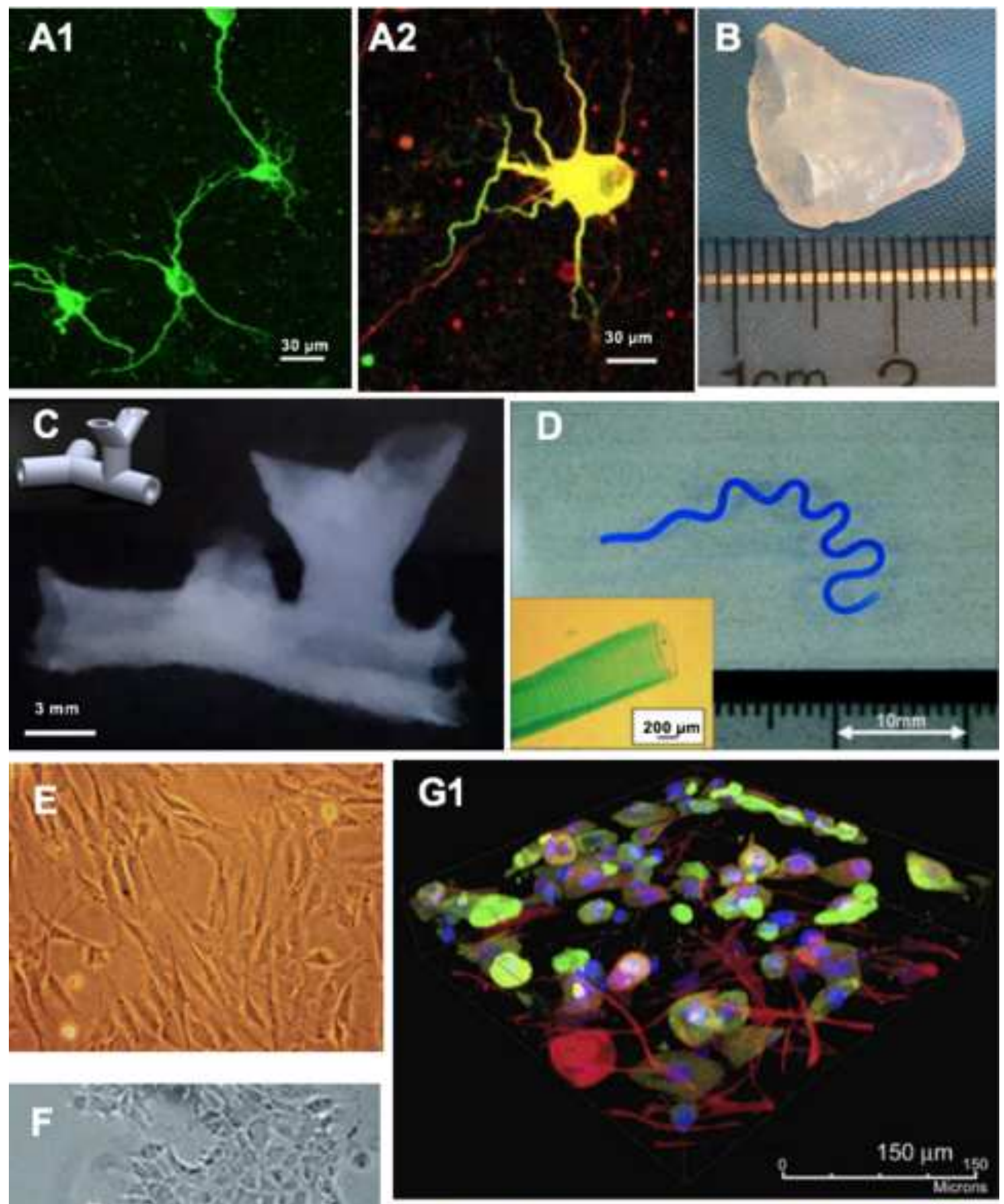

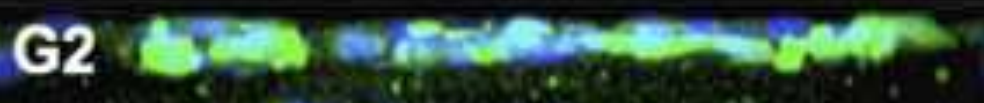

$$
150 \mu \mathrm{m}
$$

G3 


\section{A

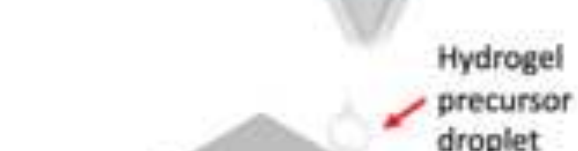

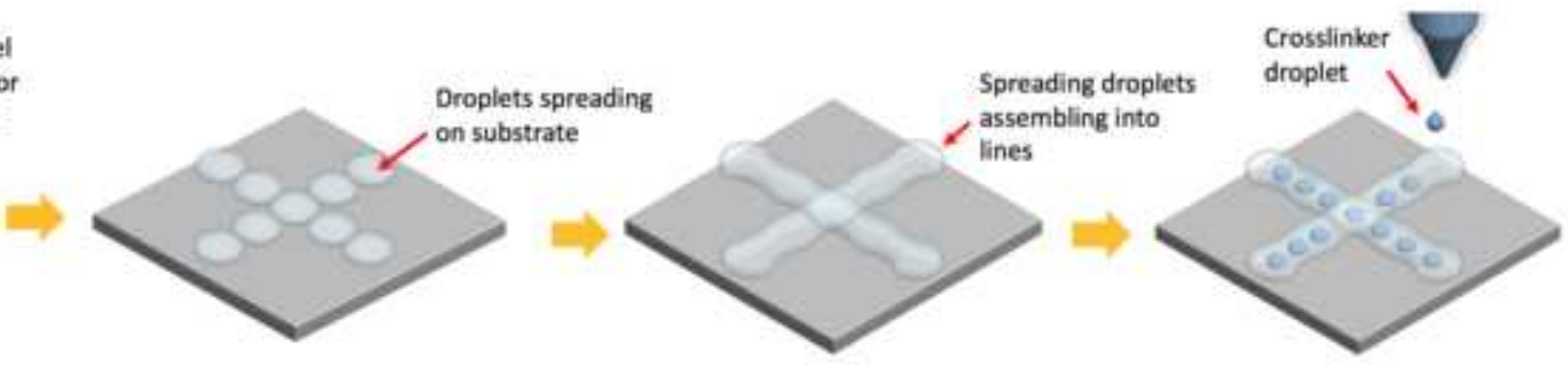

Substrate

Deposition of the bioink and crosslinker solutions in alternating layers

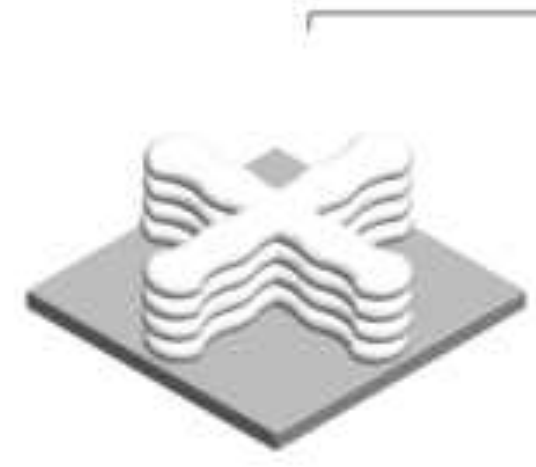

4
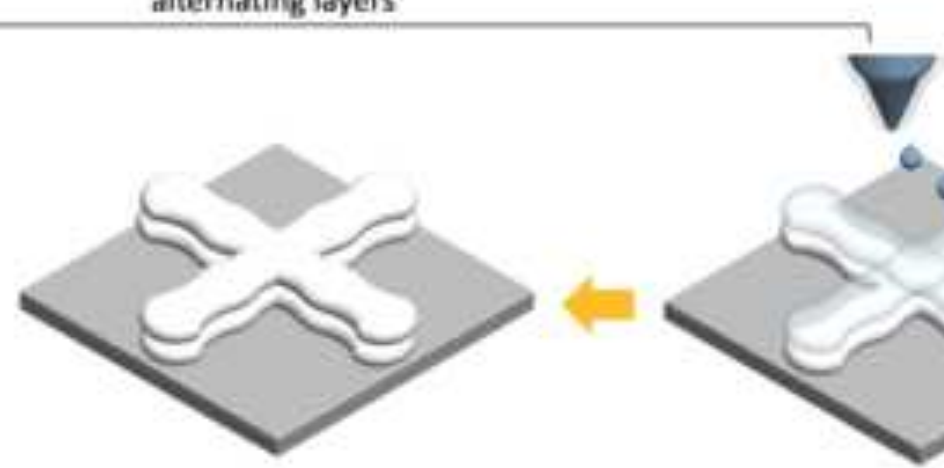

B

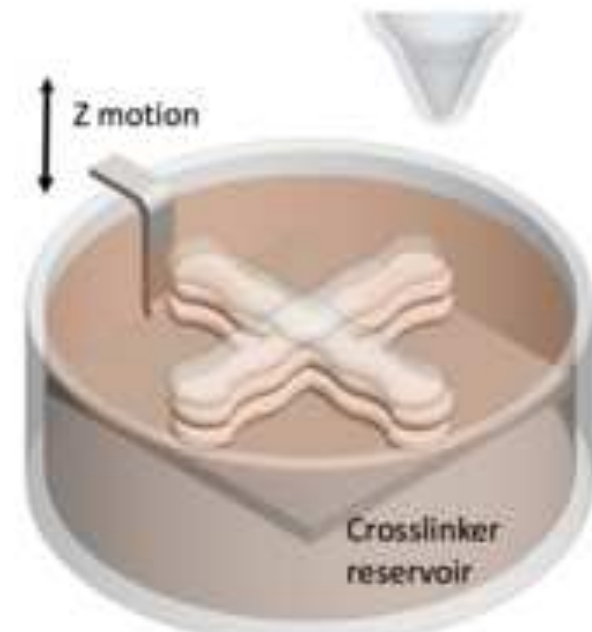

C

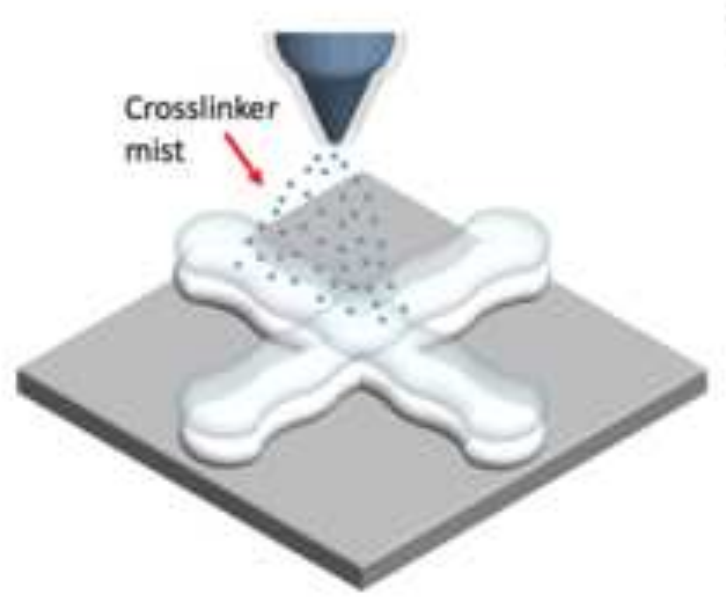

Hydrogel

crosslinking

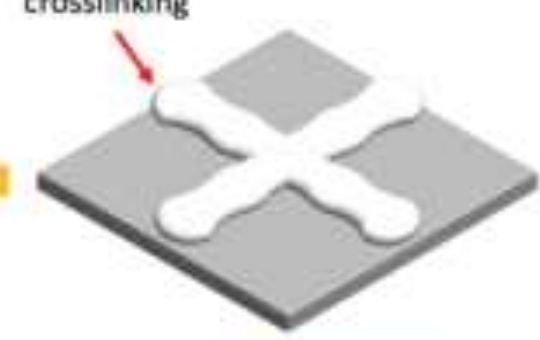

D
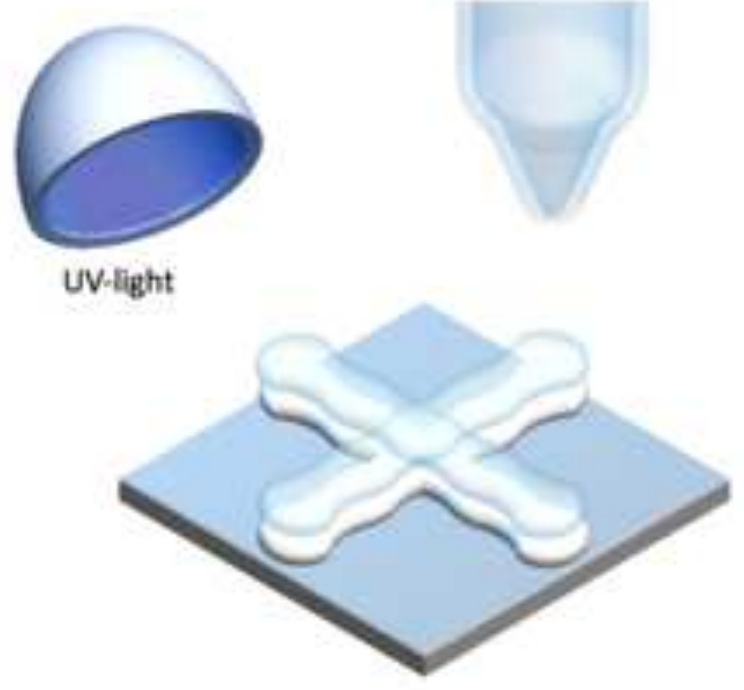
